PERM JOURNAL OF PETROLEUM AND MINING ENGINEERING

ВЕСТНИК ПНИІУ. ГЕОЛОГИЯ. НЕФТЕААЗОВОЕ И ГОРНОЕ ДЕЈЮ

ISSN 2224-9923

Volume/Toм 18 №2, 2018

http://vestnik-pstu.ru/geo/

УДК 622.276.652-047.43

Article / Статья

(C) PNRPU / ПНИПУ, 2018

\title{
A PROCEDURE FOR EVALUATION OF THE EFFECT OF WATER INJECTION INTO A RESERVOIR ON OIL PRODUCTION ON EXAMPLE OF TOURNAISIAN DEPOSITS OF THE SOSNOVSKOE GAS-OIL FIELD
}

\author{
Aleksandr P. Fadeev \\ PermNIPIneft branch of LUKOIL-Engineering LLC in Perm (29 Sovetskoy Armii st., Perm, 614066, Russian Federation)

\section{РАЗРАБОТКА МЕТОДИКИ ОЦЕНКИ ВЛИЯНИЯ ЗАКАЧКИ ВОДЫ В ПЛАСТ НА ДОБЫЧУ НЕФТИ НА ПРИМЕРЕ ТУРНЕЙСКИХ ОТЛОЖЕНИЙ СОСНОВСКОГО ГАЗОНЕФТЯНОГО МЕСТОРОЖДЕНИЯ}

\section{А.П. Фадеев}

Филиал ООО «ЛУКОЙЛ-Инжиниринг» «ПермНИПИнефть» в г. Перми (614066, г. Пермь, ул. Советской Армии, 29)

Received / Получена: 10.09.2018. Accepted / Принята: 24.10.2018. Published / Опубликована: 30.11.2018

Key words:

field, reservoir pressure maintenance system, oil production, water injection, production well, injection well, correlation coefficient, mathematical statistics, regression equation, Student's $t$-criterion, linear discriminant function, slope, optimization, Tournaisian deposits, linear discriminant analysis.

\begin{abstract}
The effect of water injection into a reservoir on oil production for Tournaisian deposits of the Sosnovskoe gas-oil field is evaluated. Statistical methods such as correlation, regression and stepwise discriminant analysis were used. Data on monthly and cumulative oil production, on amount of water injected into the reservoir from four injection and twelve production wells was used. Based on the data, studies have been performed to assess the effect of the volume of monthly water injection into the reservoir on monthly oil production, provided that each injection well affects only nearby producing wells. It was explained why there was no correlation between the parameters of monthly injection and monthly oil production. Then, in order to evaluate the efficiency of water injection into the reservoir, it was decided to use the data from the accumulated volume of water injection and the accumulated volume of oil production. It was found that there is a relationship between the parameters of the accumulated volume of water injection and the accumulated volume of oil production. The greater the accumulated volume of water injection, the greater the accumulated volume of oil production, but the gradients of increase for all wells are individual. Three areas were defined on the graphs. Relationships between the parameters have a high degree of linearity over a certain range. In order to establish the boundaries of those areas where the influence of the values of the accumulated volume of water injection on the accumulated volume of oil production is conditionally homogeneous, linear discriminant analysis was used. Results of the evaluation study show that water injection into the reservoir has a different degree of influence on the production wells. This analysis can be further applied to substantiate workovers and to identify hydrodynamic communication.
\end{abstract}

Оценено влияние закачки воды в пласт на добычу нефти для турнейских отложений Сосновского газонефтяного месторождения. Для анализа использованы статистические методы: корреляционный, регрессионный и пошаговый дискриминантный анализ. Использовалась информация по ежемесячной и накопленной добыче нефти, а также закачке воды в продуктивный пласт по четырем нагнетательным и двенадцати добывающим скважинам. На основе этой информации были выполнены исследования по оценке влияния объема месячной закачки воды в пласт на месячную добычу нефти при условии, что каждая нагнетательная скважина оказывает влияние только на близкорасположенные добывающие скважины. Между параметрами месячной закачки и месячной добычи нефти было обосновано отсутствие корреляционной зависимости. Далее для оценки эффективности нагнетания воды в пласт было принято решение использовать информацию о накопленном объеме закачки воды и накопленном объеме добычи нефти. Было установлено, что между параметрами накопленного объема закачки воды и накопленного объема добычи нефти существует зависимость, при увеличении значений накопленного объема закачки воды значение накопленного объема добычи нефти увеличивается, но градиенты повышения для всех скважин индивидуальны. На графиках визуально было выделено три участка, где соотношения между ними обладают на некотором диапазоне высокой степенью линейности. Для установления границ тех участков, где влияние значений накопленного объема закачки воды на накопленный объем добычи нефти условно однородно, был использован линейный дискриминантный анализ. Результаты исследования показывают, что закачка воды в пласт имеет разную степень влияния на добывающие скважины. Данный анализ в дальнейшем можно применять для обоснования проведения геолого-технологических мероприятий и для выявления гидродинамической связи.

Aleksandr P. Fadeev - Junior Researcher (tel. +007 98244462 27, e-mail: Aleksandr.Fadeev@pnn.lukoil.com).

Фадеев Александр Павлович - младший научный сотрудник (тел. +007 982444 62 27, e-mail: Aleksandr.Fadeev@pnn.lukoil.com). 


\section{Introduction}

Oil industry is of unsurpassed importance for the economy of our country, therefore everything that is currently related to this field is crucial. At the moment, the majority of oilfields are developed using a formation pressure maintenance system [1]. Thus, improving the effectiveness of formation pressure maintenance systems is of utmost importance for all the oilproducing enterprises. In developing an oilfield, it is very important to achieve the highest possible economic effectiveness of oil production, therefore, it is necessary to assess how the implemented formation pressure maintenance system operates $[2,3]$.

The improvement of methods for analyzing the formation pressure maintenance system is a regular process as it is one of the fundamental and the cheapest method of formation stimulation, while the task of involving poorly drainable formation areas into development is quite challenging [4].

Dealing with the task of evaluating and forecasting the effectiveness of different kinds of flooding system and its control is significantly facilitated, if there is an operating geological and hydrodynamic model in place, however, far from all the development targets have it, as the developing such models is a labour-intensive and quite expensive process. Therefore, this paper makes a special emphasis on the methodology of evaluating the effectiveness of formation pressure maintenance system using readily available oilfield information.

\section{General geological characteristic of sosnovskoye oilfield}

Sosnovskoe oilfield was discovered in 1967 by the Well No. 42 as a result of prospecting and exploration drilling.

In administrative terms, the oilfield in located in Ordinsky District of Perm region, $100 \mathrm{~km}$ south of the Krai centre - the city of Perm (Fig. 1). The nearest localities include the villages of Orda, Sosnovka and Ashap.

The information about the depth of formation and the ranges of stratigraphic divisions' thickness changes were received as a result of drilling 41 wells, including 11 prospecting and exploration and 30 producing wells.

The surface of crystalline basement is located at the depth of about $7 \mathrm{~km}$ submersing in the south-west direction. The basement is represented by crystalline rocks.

The section of Sosnovskoe oilfield represents a sedimentary complex typical of Permian and Bashkir anticlines and Bymsko-Kungurskaya depression and consists predominantly of carbonate rocks. It is favourable in terms of sedimentation conditions and opportunities of hydrocarbon deposits development.

The section contains no Lower Devonian sediments. Middle Devonian sediments with stratigraphic nonconformity rest on Vendian ones. There are no rocks of Cambrian, Ordovician or Silurian ages.

Radaevian sediments rest unconformably on the eroded roof of Tournaisian sediments (no Kosvinsky horizon).
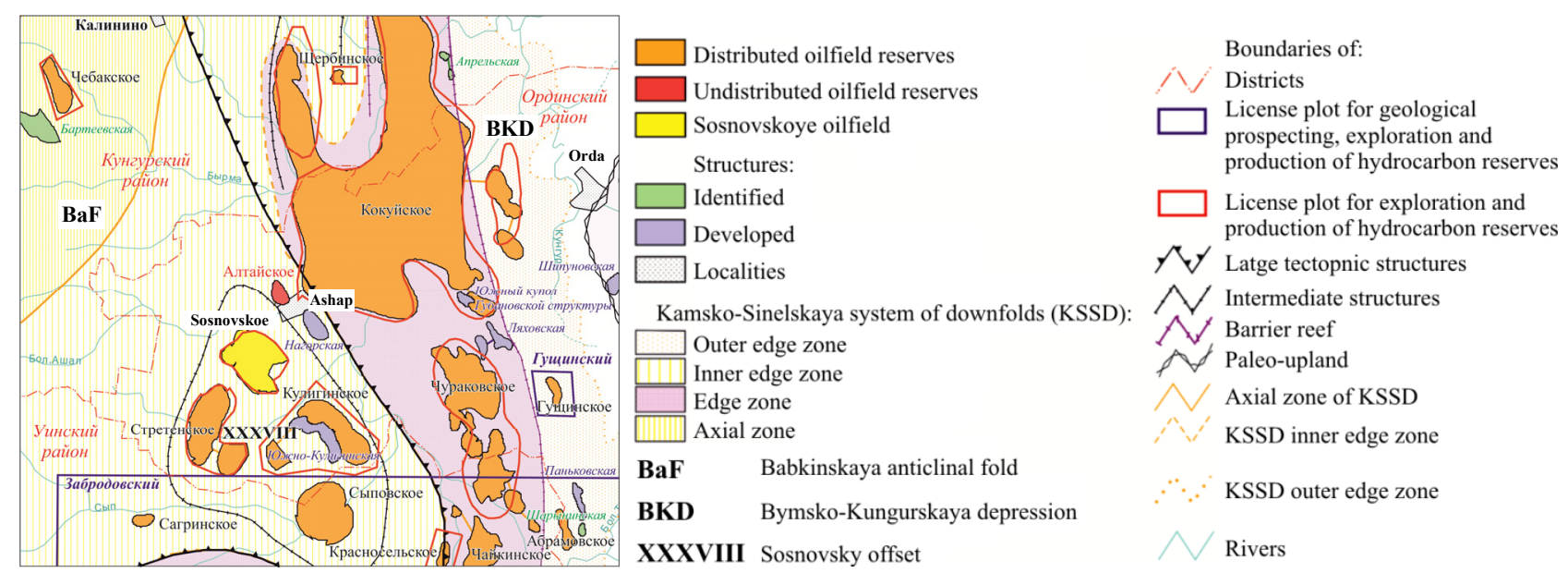

Fig. 1. Extract from the tectonic map of the study area 
Mesozoic deposits are not present in the section due to a long break in the sedimentation.

Quarternary deposits are met everywhere and rest with stratigraphic nonconformity on Perm deposits.

In tectonic terms, Sosnovskoe oilfield is located in Babkinskaya anticlinal fold within Sosnovsky offset, in the inner edge zone adjacent to Kamsko-Sinelskaya system of downfolds.

Drilling and well tests have proved the presence of oil-and-gas content in Devonian terrigenous (formation $\mathrm{D}_{0}$ ), Upper Devonian and Tournaisian carbonate (formation $\mathrm{T}_{1}$ ), Lower and Middle Visean terrigenous (formations $\mathrm{Tl}_{1 \mathrm{a}}, \mathrm{Tl}_{2 \mathrm{a}}, \mathrm{Tl}_{2 \mathrm{~b}}, \mathrm{Bb}_{1}$ ), Upper Visean Bashkir carbonate (formation Bsh) and Middle Carboniferous terrigenous and carbonate (formation $\mathrm{V}_{3} \mathrm{~V}_{4}$ ) oil-and-gas bearing complexes.

Production assets under review $-\mathrm{T}_{1}$.

Brief geological and physical characteristic of $\mathrm{T}_{1}$ : sand content -0.37 unit fractions, porosity -0.13 unit fractions, oil-and-gas content -0.83 unit fractions, permeability (geophysical well logging) $-0.068 \mu \mathrm{m}^{2}$, number of permeable intervals -5 pcs, gas saturation pressure - $12.11 \mathrm{MPa}$, current formation pressure 15.5 MPa. Average formation water cut amounts to $57.6 \%$ with the production of initial recoverable reserves of $10 \%$. Production asset $\mathrm{T}_{1}$ ranks first among other production assets of Sosnovskoye oilfield by its reserves (5,376 thousand tons) [5]. The oilfield is at the $3^{\text {rd }}$ stage of development.
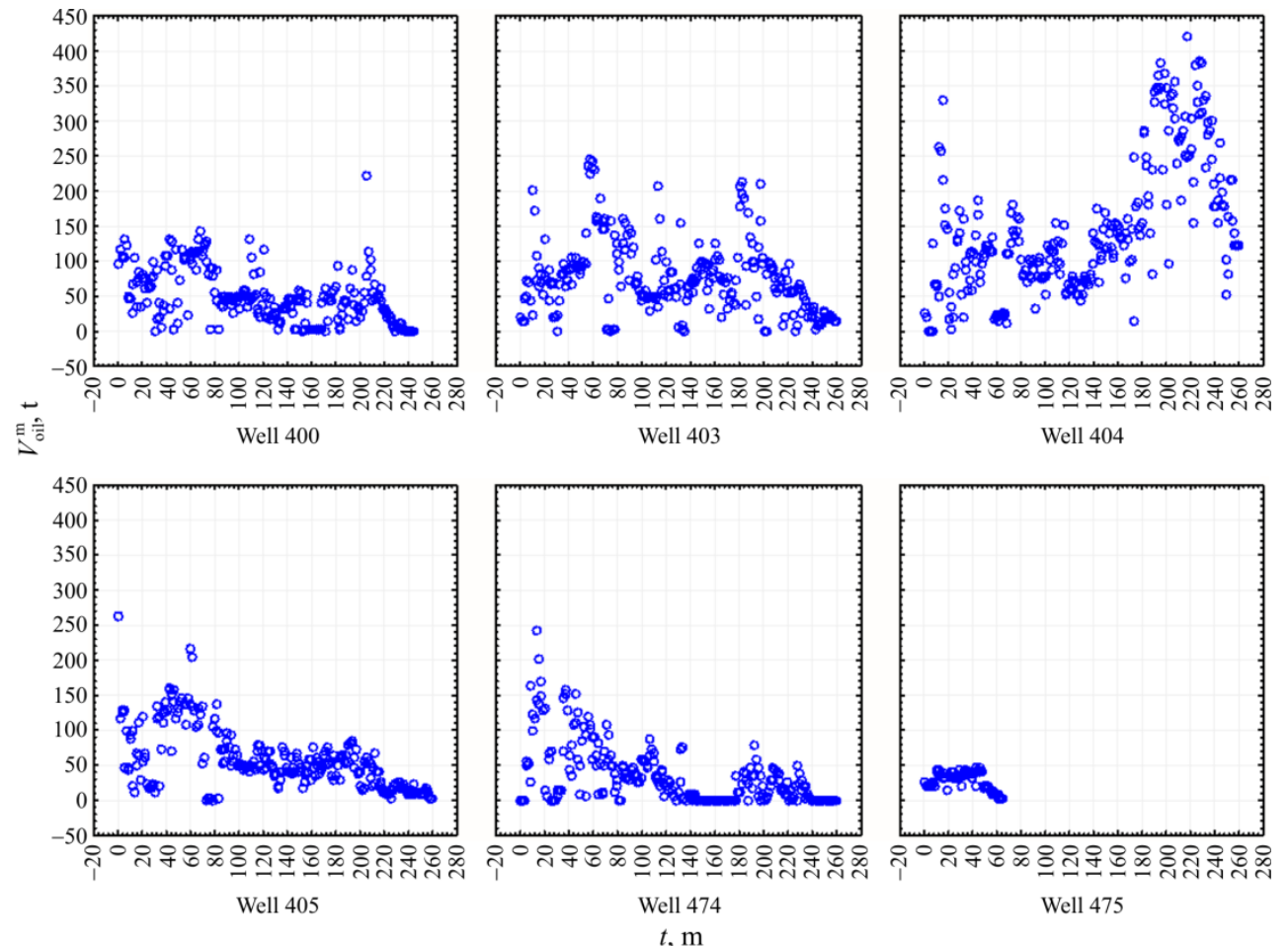
system of $\mathrm{T}_{1}$ formation.

\section{Assessment of impact of water injection into the formation on oil production on the example of tournaisian deposits of Sosnovskoe oil and gas field} 2016 , i.e. for 259 months $(n=259)$. production $V_{\text {oil }}^{\mathrm{m}}$. Equation.DSMT4 in time $t$ is shown in Fig. 2. recoverable reserves of $10 \%$, it is necessary to analyze the formation pressure maintenance

The method of assessing the impact of water injection into the formation on oil production for Well 401. The method of assessing the impact of water injection into the formation on the production of oil uses the information about Well 401 for the period from August, 1993, to February,

On the basis of this information we will assess the impact of the monthly volume of water injected into the formation $V_{\mathrm{H}_{2} \mathrm{O}}^{\mathrm{m}}$ on the monthly oil

For the purposes of the method development, the values of $V_{\mathrm{H}_{2} \mathrm{O}}^{\mathrm{m}}$ for the injection wells located in different reservoir areas were used. We assume that the injection of water into this well will have an impact on the monthly production of oil by wells 400 , 403-405, 474, 475. The change of values of EMBED

Fig. 2. Change of values of $V_{\mathrm{oil}}^{\mathrm{m}}$ in time $t$ by wells 
The analysis of Fig. 2 shows that the values of $V_{\text {oil }}^{\mathrm{m}}$ differ materially by well.

The change of values of $V_{\mathrm{H}_{2} \mathrm{O}}^{\mathrm{m}}$ in time for Well 424 is shown in Fig. 3.

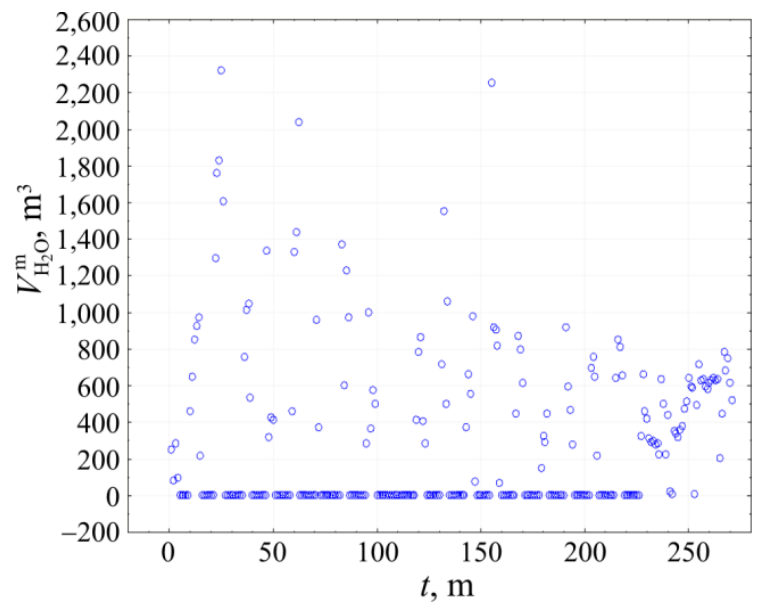

Fig. 3. Change of $V_{\mathrm{H}_{2} \mathrm{O}}^{\mathrm{m}}$ values in time for Well 424

The change of values of $V_{\mathrm{H}_{2} \mathrm{O}}^{\mathrm{m}}$ depending on $t$ has quite a complex view.

In order to compare the values of $V_{\mathrm{H}_{2} \mathrm{O}}^{\mathrm{m}}$ and $V_{\text {oil }}^{\mathrm{m}}$ for the two reviewed options of impact of the injection wells, correlation fields set out in Fig. 4 were built for the injections wells.
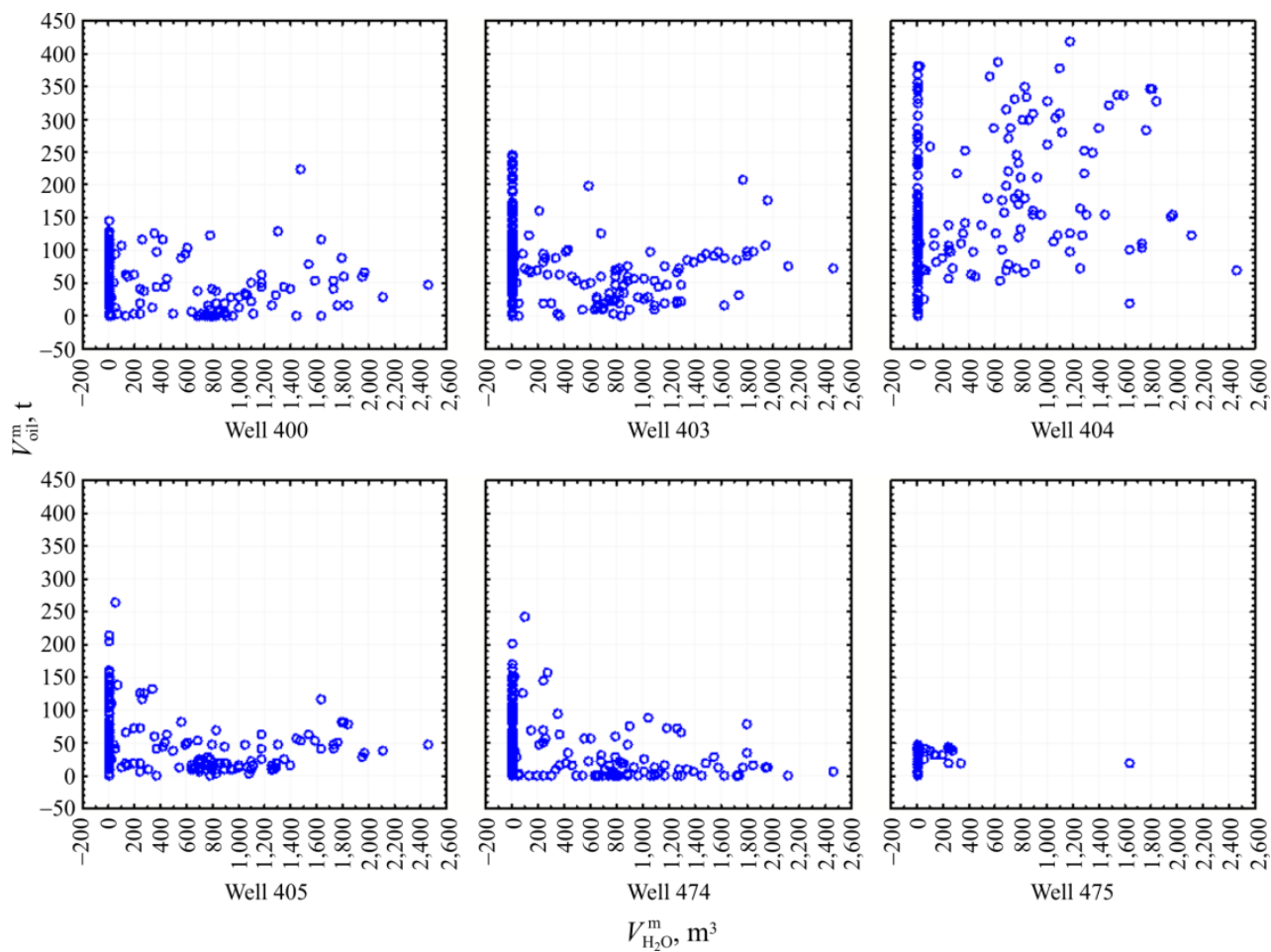

Fig. 4. Field of correlation between $V_{\mathrm{H}_{2} \mathrm{O}}^{\mathrm{m}}$ and $V_{\text {oil }}^{\mathrm{m}}$ 
Table 1 increase, the values of $V_{\text {oil }}$ also go up, however, the

The constant and slope terms and correlation ratio of regression equation showing the dependence of $V_{\mathrm{oil}}^{\mathrm{m}}$ on $V_{\mathrm{H}_{2} \mathrm{O}}^{\mathrm{m}}$ (upper line), dependence of $V_{\text {oil }}$ on $V_{\mathrm{H}_{2} \mathrm{O}}$ (lower line) for Well 401

\begin{tabular}{|c|c|c|c|}
\hline Well & Constant & Slope term & Correlation ratio $r$ \\
\hline 400 & $\underline{52.973}$ & $\frac{-0.009}{0.142}$ & $\frac{-0.126}{0.851}$ \\
\hline 403 & $\frac{83.907}{5796.922}$ & $\frac{-0.018}{0.23}$ & $\frac{-0.183}{0.897}$ \\
\hline 404 & $\underline{126.459}$ & $\frac{0.062}{0.435}$ & $\frac{0.349}{0.986}$ \\
\hline 405 & $\frac{67.508}{6100,174}$ & $\frac{-0.026}{0.155}$ & $\frac{-0.323}{0.841}$ \\
\hline 474 & $\frac{40.766}{4372,232}$ & $\frac{-0.019}{0.077}$ & $\frac{-0.237}{0.75}$ \\
\hline 475 & $\frac{28.31}{241.74}$ & $\frac{-0.001}{0.612}$ & $\frac{-0.016}{0.953}$ \\
\hline All wells & $\frac{71.603}{4701.201}$ & $\frac{0.0005}{0.222}$ & $\frac{0.0041}{0.749}$ \\
\hline
\end{tabular}

In order to assess the effectiveness of water injection into the formation it is proposed to use the dependence of impact rendered by the accumulated volume of injected water $\left(V_{\mathrm{H}_{2} \mathrm{O}}\right)$ on the accumulated oil production $\left(V_{\text {oil }}\right)$ based on the information for 259 months.

The dependencies of $V_{\text {oil }}$ on $V_{\mathrm{H}_{2} \mathrm{O}}$ for the wells under review are shown in Fig. 5.

It can be seen that as opposed to the previous graphs, in these graphs when the values of $V_{\mathrm{H}_{2} \mathrm{O}}$ gradients are individual for each well. The values of $r$ and regression equations of $V_{\text {oil }}$ dependence on $V_{\mathrm{H}_{2} \mathrm{O}}$ are set out in Table 1. The values of $r$ are high for all the wells and statistically significant by $t$ criteria, which may indicate an actual impact of $V_{\mathrm{H}_{2} \mathrm{O}}$ on $V_{\text {oil }}$ across all the wells.

The analysis of dependencies of $V_{\text {oil }}$ on $V_{\mathrm{H}_{2} \mathrm{O}}$, set out in Fig. 5, shows that in all the cases within the graph there are three areas, which can be visually observed, where the correlations feature high degree of linearity in a certain range. In order to determine the boundaries of these almost linear sections, where the impact of $V_{\mathrm{H}_{2} \mathrm{O}}$ values on $V_{\text {oil }}$ is relatively homogenous, we will use the linear discriminant analysis (LDA). The options for the application of statistical methods of analysis in academic research to solve similar tasks are set out in studies [6-23].

Plotting the graph of a linear discriminant function (LDF) is performed in the following manner.

If we designate as $X_{i j}$ the value of the variable under number $i$ in the point of observation under number $j$, taken from the sample within the first correlation interval in respect of $V_{\text {oil }}$ and $V_{\mathrm{H}_{2} \mathrm{O}}$, then we will get the matrix $W_{1}$ with degree $m$ and $n_{1}$ showing the results of observations over this sample:
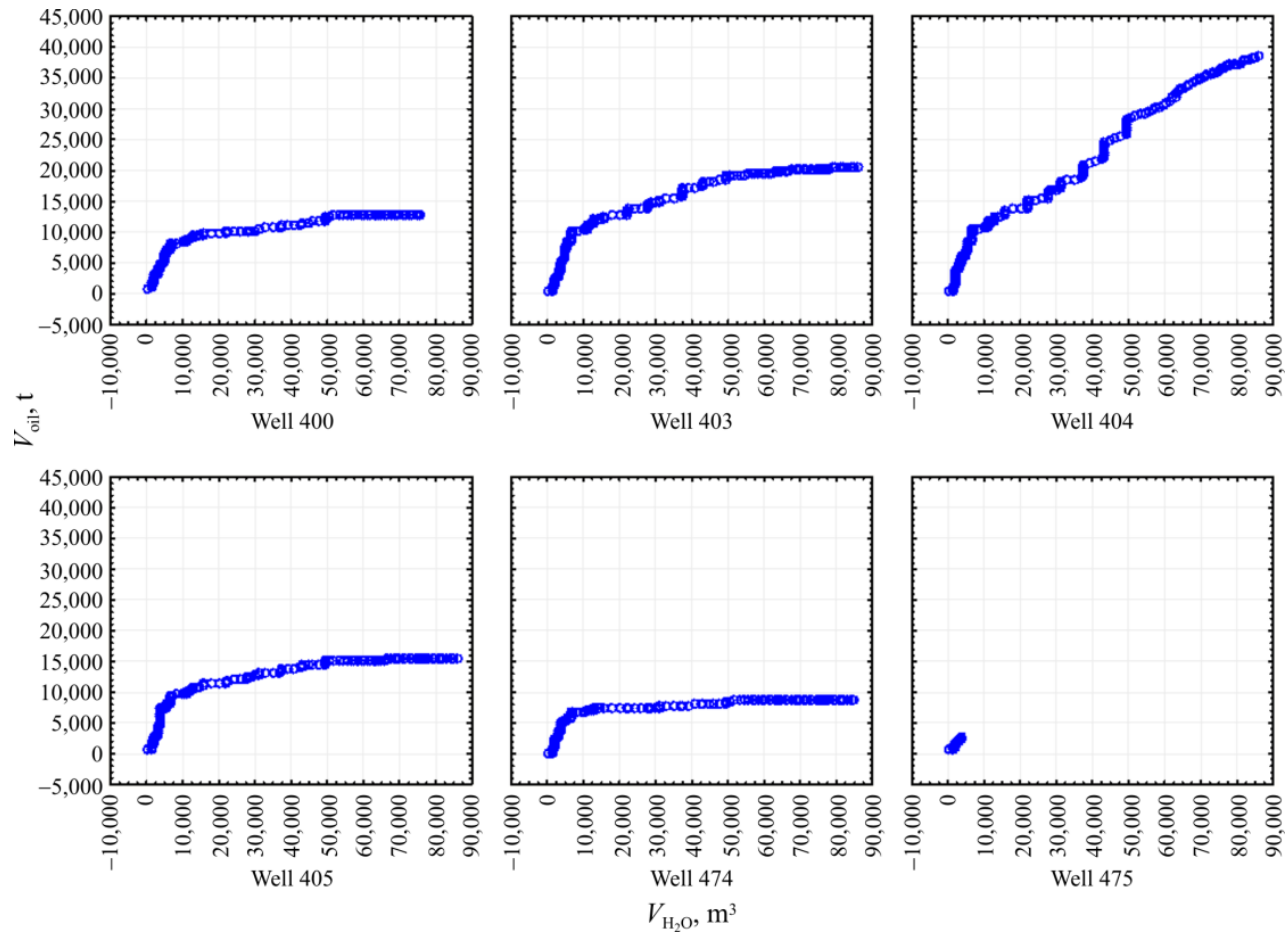

Well 404

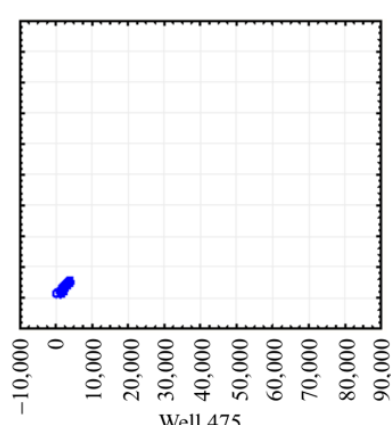

Well 475

Fig. 5. Change in $V_{\text {oil }}$ values depending on $V_{\mathrm{H}_{2} \mathrm{O}}$ by well 


$$
W_{1}=\left[\begin{array}{cccc}
X_{11} & X_{12} & \cdot & X_{1 n_{1}} \\
X_{21} & X_{22} & \cdot & X_{2 n_{1}} \\
\cdot & \cdot & \cdot & \cdot \\
X_{m_{1}} & X_{m_{2}} & \cdot & X_{m n_{1}}
\end{array}\right] .
$$

Designating as $X_{i j}^{1}$ the result of measuring the variable under number $i$ in the point under number $j$, taken from the second correlation interval, we will get the matrix $W_{2}$ with degree $m \times n_{2}$ :

$$
W_{2}=\left[\begin{array}{cccc}
X_{11}^{1} & X_{12}^{1} & \cdot & X_{1 n_{2}} \\
X_{21}^{1} & X_{22}^{1} & \cdot & X_{2 n_{2}}^{1} \\
\cdot & \cdot & \cdot & \cdot \\
X_{m_{1}}^{1} & X_{m_{2}}^{1} & \cdot & X_{m n_{2}}^{1}
\end{array}\right] .
$$

Designating as $X_{i j}^{2}$ the result of measuring the variable under number $i$ in the point under number $j$, taken from the third correlation interval, we will get the matrix $W_{3}$ with degree $m \times n_{3}$ :

$$
W_{3}=\left[\begin{array}{cccc}
X_{11}^{2} & X_{12}^{2} & \cdot & X_{1 n_{2}} \\
X_{21}^{2} & X_{22}^{21} & \cdot & X_{2 n_{2}}^{2} \\
\cdot & \cdot & \cdot & \cdot \\
X_{m_{1}}^{2} & X_{m_{2}}^{2} & \cdot & X_{m n_{2}}^{2}
\end{array}\right],
$$

where $m$ is the number of indicators; $n_{1}, n_{2}, n_{3}$ is the sample volume.

In order to plot LDF, the matrixes of centered sums of squares and shifted products are composed for calculating the sample matrix.

Then, a reverse sample covariance matrix $C$ is found for determining the ratios of the linear discriminant function.

Then, boundary values of discriminant functions $\left(R_{\mathrm{o}}\right)$ are determined, which divide the sample into three subsets [24-27].

They are used to calculate linear discriminant functions, to determine the percentage of correct discernment until the entire sample is divided into three non-crossing classes [28-31]. We will now show an example of plotting the linear discriminant function for Wells 400 and 401.

$$
Z_{1}=0,000478 V_{\mathrm{H}_{2} \mathrm{O}}-0,003641 V_{\text {oil }}+9,87395
$$

with $R=0,928, \chi^{2}=692,49, p=0,000000$.

$$
Z_{2}=-0,0003 V_{\mathrm{H}_{2} \mathrm{O}}+0,00064 V_{\text {oil }}-2,22779
$$

with $R=0,655, \chi^{2}=143,18, p=0,000000$, where $V_{\text {oil }}$ is the volume of accumulated oil, tons ( $Q_{\text {oil }}$ accumulated, tons), $V_{\mathrm{H}_{2} \mathrm{O}}$ the accumulated injection volume $\left(Q_{\text {injection }}\right.$ accumulated, $\left.\mathrm{m}^{3}\right)$. The first boundary has $V_{\mathrm{H}_{2} \mathrm{O}}=5084 \mathrm{~m}^{3}$, the second $43,277 \mathrm{~m}^{3}$.

Using these boundaries, we have composed regression equations for the dependence of $V_{\text {oil }}$ on $V_{\mathrm{H}_{2} \mathrm{O}}$ (Table 2). LDFs were also plotted for other wells, which were used to determine the classes' boundaries for the dependence of $V_{\text {oil }}$ on $V_{\mathrm{H}_{2} \mathrm{O}}$, within which regression equations were composed (see Table 2) [32-36].

Table 2

Assessment of impact of $V_{\mathrm{H}_{2} \mathrm{O}}$ in the injection well 401 on $V_{\text {oil }}$ in producing wells 400 , 403-405, 474, 475

\begin{tabular}{|l|c|c|c|}
\hline $\begin{array}{c}\text { Interval of values } \\
V_{\mathrm{H}_{2} \mathrm{O}}, \mathrm{m}^{3}\end{array}$ & Constant & Slope term & $\begin{array}{c}\text { Correlation } \\
\text { ratio } r\end{array}$ \\
\hline $0-5,084$ & 174.805 & 1.066 & 0.951 \\
\hline $5,084-43,277$ & $7,008.907$ & 0.113 & 0.914 \\
\hline Over 43,277 & $10,673.574$ & 0.034 & 0.819 \\
\hline \multicolumn{4}{|c|}{ Well 403 } \\
\hline $0-5,084$ & -990.09 & 1.380 & 0.956 \\
\hline $5,084-58,426$ & $7,835.362$ & 0.228 & 0.973 \\
\hline Over 58,426 & $17,682.610$ & 0.034 & 0.978 \\
\hline \multicolumn{4}{|c|}{ Well 404 } \\
\hline $0-3,942$ & $-1,524.131$ & 1.897 & 0.899 \\
\hline $3,942-43,277$ & $6,267.128$ & 0.373 & 0.976 \\
\hline Over 43,277 & $9,846.542$ & 0.349 & 0.989 \\
\hline \multicolumn{4}{|c|}{ Well 405 } \\
\hline $0-3,942$ & -850.407 & 1.521 & 0.956 \\
\hline $3,942-57,535$ & $7,821.541$ & 0.153 & 0.950 \\
\hline Over 57,535 $14,066.0569$ & 0.019 & 0.992 \\
\hline \multicolumn{4}{|c|}{ Well 474 } \\
\hline $0-3,942$ & $-1,193.225$ & 1.388 & 0.874 \\
\hline $3,942-50,735$ & $5,666.771$ & 0.064 & 0.833 \\
\hline Over 50,735 & $8,123.062$ & 0.011 & 0.891 \\
\hline \multicolumn{4}{|c|}{ Well 475 } \\
\hline $0-1,780$ & $-3,351.323$ & 2.584 & 0.754 \\
\hline $1,780-3,107$ & 535.3272 & 0.545 & 0.967 \\
\hline Over 3,107 $1,519.468$ & 0.272 & 0.654 \\
\hline
\end{tabular}

It can be seen that the impact of $V_{\mathrm{H}_{2} \mathrm{O}}$ on $V_{\text {oil }}$ of the Well 401 is different in the highlighted intervals. We note that for all the wells the minimum impact is observed in the third interval (minimum slope term) and maximum - in the first. 
The dependence of accumulated oil production on the accumulated injection in the third interval is presented in Fig. 6.

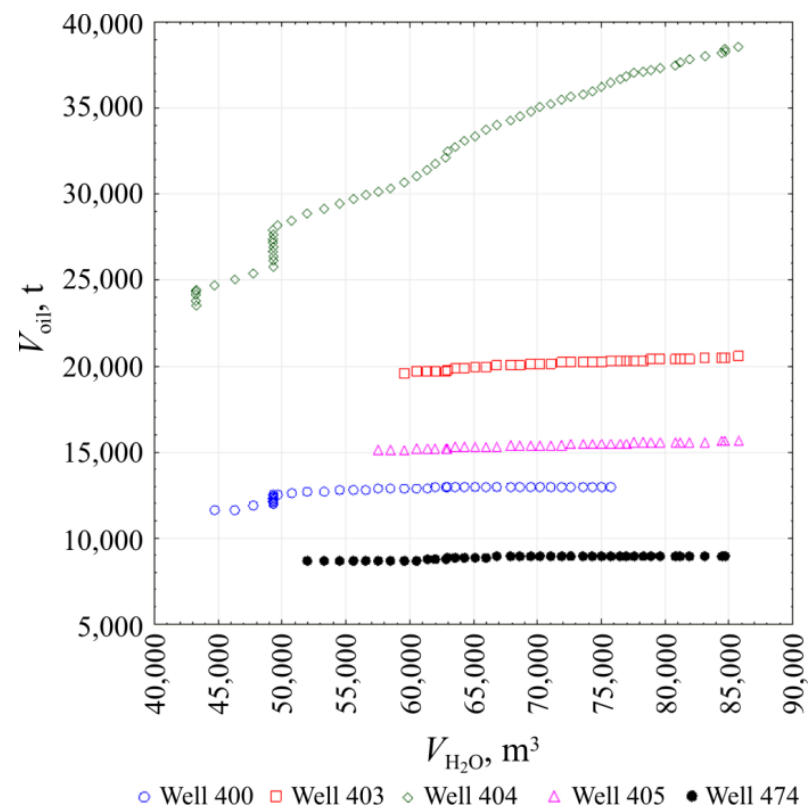

Fig. 6. Change in the values of $V_{\text {oil }}$ depending on

$V_{\mathrm{H}_{2} \mathrm{O}}$ in the third interval

Regression equations between injection well 401 and producing wells:

Well 400: $V_{\text {oil }}=10,673.574+0.0338 V_{\mathrm{H}_{2} \mathrm{O}}$;

Well 403: $V_{\text {oil }}=17,682.6099+0.034 V_{\mathrm{H}_{2} \mathrm{O}}$;
Well 404: $V_{\text {oil }}=9,846.5421+0.3493 V_{\mathrm{H}_{2} \mathrm{O}}$;

Well 405: $V_{\text {oil }}=14,066.0569+0.0188 V_{\mathrm{H}_{2} \mathrm{O}}$;

Well 474: $V_{\text {oil }}=8,123.0623+0.0107 V_{\mathrm{H}_{2} \mathrm{O}}$.

Having analyzed the obtained graph and regression equation, we can say that the highest slope term is featured by the Well $404(0.3493)$ and the lowest - by Well $474(0.0107)$. The slope term of other wells ranges from 0.0188 to 0.034 .

Method of assessing the impact of water injection into the formation on oil production for Well 407. The method of assessing the impact of water injection into the formation on the production of oil uses the information on Well 407 for the period from July, 1993, to June, 2015, i.e. for 264 months $(n=264)$.

On the basis of this information we will assess the impact of the monthly volume of water injected into the formation $V_{\mathrm{H}_{2} \mathrm{O}}^{\mathrm{m}}$ on the monthly oil production $V_{\text {oil }}^{\mathrm{m}}$.

For the purposes of the method development, the values of $V_{\mathrm{H}_{2} \mathrm{O}}^{\mathrm{m}}$ for the injection wells located in different reservoir areas were used. We assume that the injection of water into this well will have an impact on the monthly production of oil by wells 403, 405, 474, 475, 478. The change of values of $V_{\text {oil }}^{\mathrm{m}}$ in time $t$ is shown in Fig. 7.
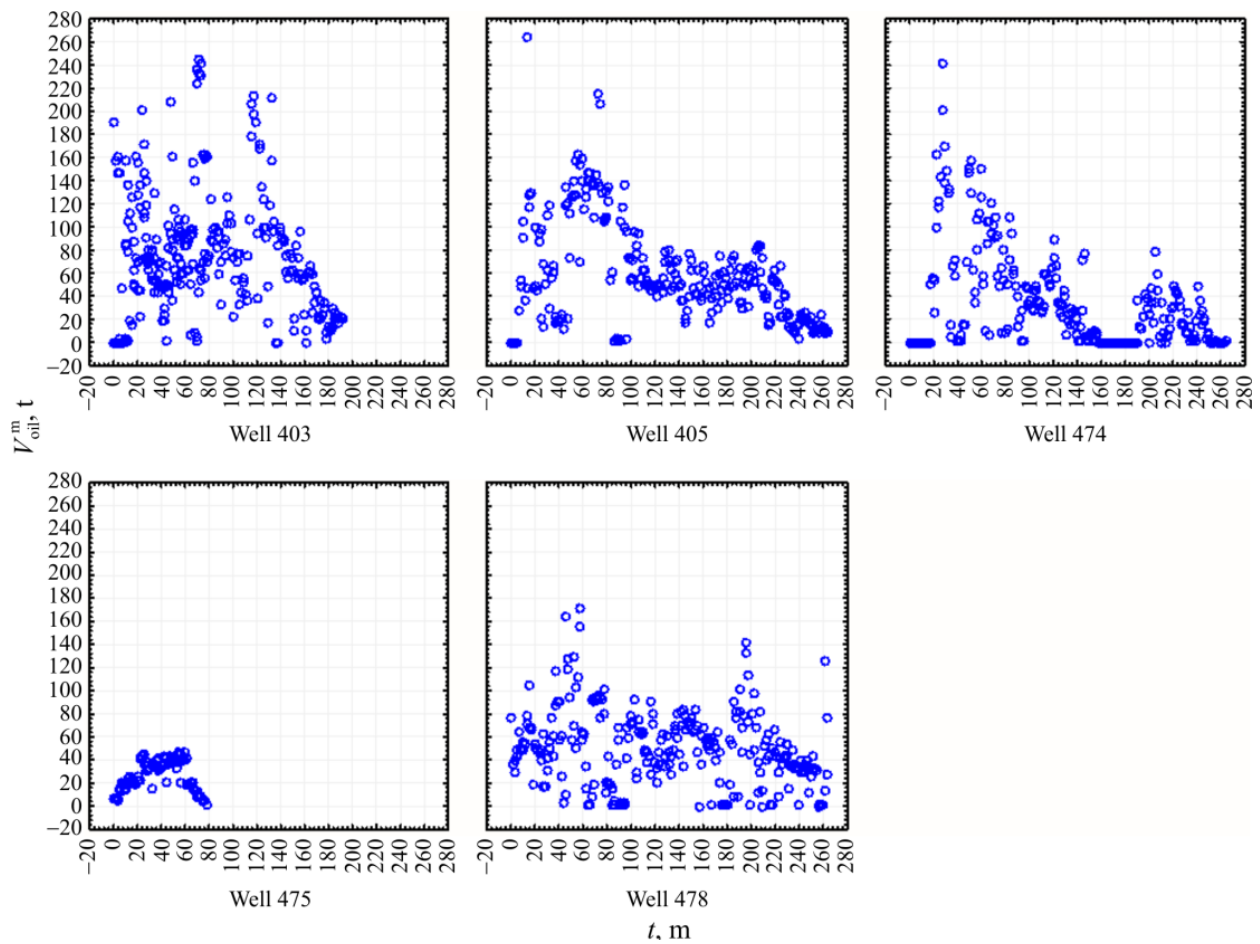

Fig. 7. Change of values of $V_{\text {oil }}^{\mathrm{m}}$ in time $t$ by wells 
It is seen that the values of $V_{\text {oil }}^{\mathrm{m}}$ vary significantly by well.

The change of values of $V_{\mathrm{H}_{2} \mathrm{O}}^{\mathrm{m}}$ in time for Well 407 is shown in Fig. 8.

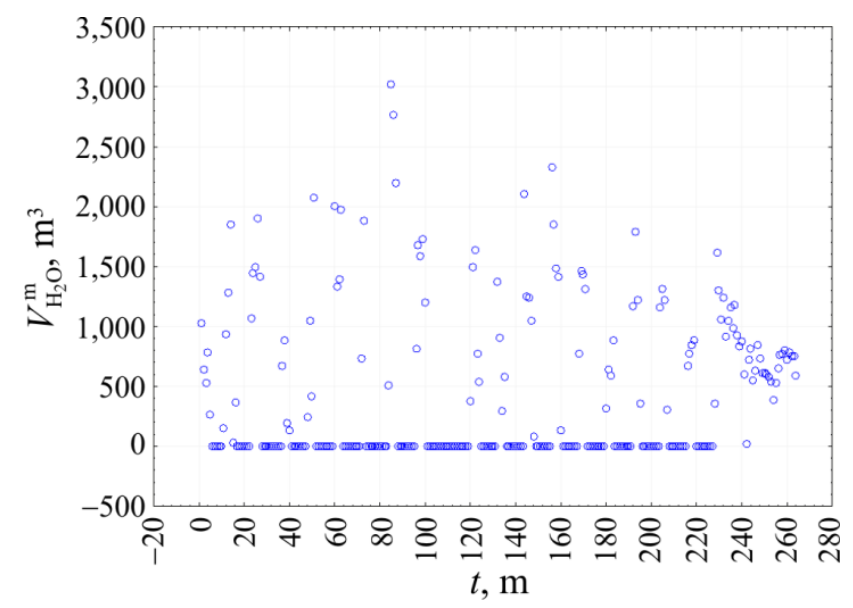

Fig. 8. Change of values of $V_{\mathrm{H}_{2} \mathrm{O}}^{\mathrm{m}}$ in time for the Well 407

According to Fig. 8, the dependence of $V_{\mathrm{H}_{2} \mathrm{O}}^{\mathrm{m}}$ values on $t$ has a quite complicated form.

In order to compare the values of $V_{\mathrm{H}_{2} \mathrm{O}}^{\mathrm{m}}$ and $V_{\text {oil }}^{\mathrm{m}}$ for the two reviewed options of impact of the injection wells, correlation fields set out in Fig. 9 were built for the injections wells.
The values of $V_{\mathrm{H}_{2} \mathrm{O}}^{\mathrm{m}}$ and $V_{\text {oil }}^{\mathrm{m}}$ have a weak correlation, i.e. it is impossible to prove in statistical terms the impact of $V_{\mathrm{H}_{2} \mathrm{O}}^{\mathrm{m}}$ values on $V_{\text {oil }}^{\mathrm{m}}$ values. Now we are going to prove this statement with the calculations of $r$ and making regression equations $V_{\mathrm{oil}}^{\mathrm{m}}$ (oil production for a month, tons) will be a dependent attribute, and $V_{\mathrm{H}_{2} \mathrm{O}}^{\mathrm{m}}$ (water injection into the formation for a month, $\mathrm{m}^{3}$ ) will be an independent factor.

As a result of this method application, the values of $r$ were calculated and regression equations were made for the following options:

Based on the information about each well;

b) based on the information about all wells.

The values of $r$ and regression equations of $V_{\text {oil }}^{\mathrm{m}}$ dependence on $V_{\mathrm{H}_{2} \mathrm{O}}^{\mathrm{m}}$ in the above options are set out in Table 3.

The analysis of the constant and slope terms of a regression equation and $r$ ratio indicates that it is not possible to measure the impact of $V_{\mathrm{H}_{2} \mathrm{O}}^{\mathrm{m}}$ on $V_{\text {oil }}^{\mathrm{m}}$ using the provided regression equations. This is especially evident if we look at very low values of $r$ ratios.
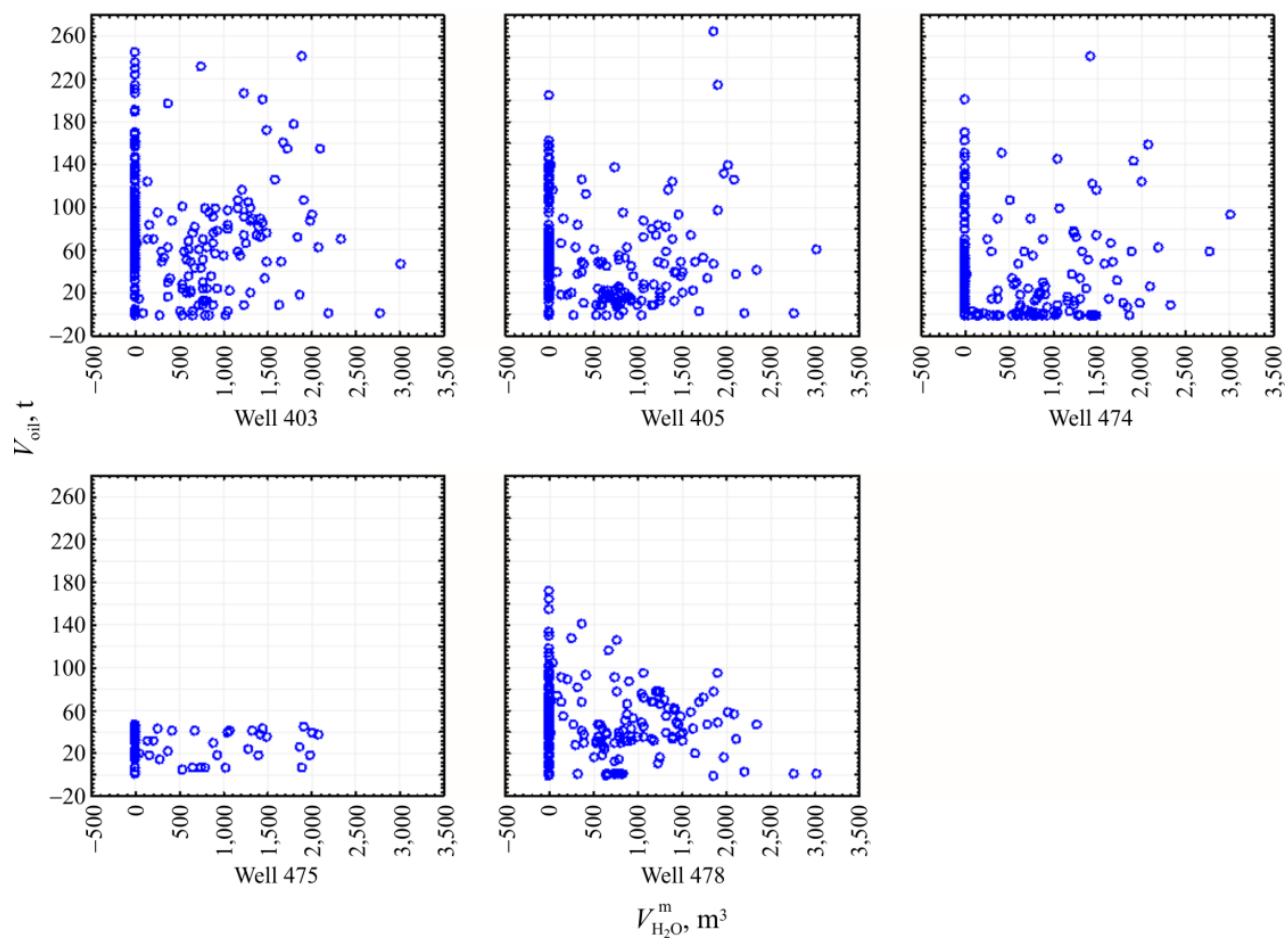

Fig. 9. Correlation plot of $V_{\mathrm{H}_{2} \mathrm{O}}^{\mathrm{m}}$ and $V_{\text {oil }}^{\mathrm{m}}$ 
Table 3

Constant and slope terms and correlation ratio of regression equation showing the dependence of $V_{\text {oil }}^{\mathrm{m}}$ on $V_{\mathrm{H}_{2} \mathrm{O}}^{\mathrm{m}}$ (upper line), dependence of $V_{\text {oil }}$ on $V_{\mathrm{H}_{2} \mathrm{O}}$ (lower line) for Well 407

\begin{tabular}{|c|c|c|c|}
\hline Well & Constant & Slope term & $\begin{array}{l}\text { Correlation } \\
\text { ratio } r\end{array}$ \\
\hline 403 & $\frac{79.540}{-534.195}$ & $\frac{-0.005}{0.210}$ & $\frac{-0.063}{0.990}$ \\
\hline 405 & $\frac{62.82}{1,060.251}$ & $\frac{-0.009}{0.1539}$ & $\frac{-0.128}{0.974}$ \\
\hline 474 & $\frac{31.497}{1,414.276}$ & $\frac{0.005}{0.084}$ & $\frac{0.081}{0.930}$ \\
\hline 475 & $\frac{24.855}{379.986}$ & $\frac{0.003}{0.079}$ & $\frac{0.131}{0.978}$ \\
\hline 478 & $\frac{54.048}{2,296.74}$ & $\underline{0.008}$ & $\frac{-0.153}{0.990}$ \\
\hline All wells & $\frac{54.647}{741.962}$ & $\frac{0.004}{0.148}$ & $\frac{-0.048}{0.888}$ \\
\hline
\end{tabular}

In order to assess the effectiveness of water injection into the formation, it is proposed to use the dependence of impact rendered by the accumulated volume of injected water $\left(V_{\mathrm{H}_{2} \mathrm{O}}\right)$ on the accumulated oil production $\left(V_{\text {oil }}\right)$ based on the information for 264 months. The dependencies of $V_{\text {oil }}$ on $V_{\mathrm{H}_{2} \mathrm{O}}$ for the wells under review are shown in Fig. 10.
The analysis of information in Fig. 10 allowed concluding that as opposed to the previous graphs, in these graphs when the values of $V_{\mathrm{H}_{2} \mathrm{O}}$ increase, the values of $V_{\text {oil }}$ also go up, however, the gradients are individual for each well. The values of $r$ and regression equations of $V_{\text {oil }}$ on $V_{\mathrm{H}_{2} \mathrm{O}}$ are set out in Table 4. The values of $r$ are high for all the wells and statistically significant by $t$ criteria, which may indicate an actual impact of $V_{\mathrm{H}_{2} \mathrm{O}}$ on $V_{\text {oil }}$ across all the wells.

The analysis of dependencies of $V_{\text {oil }}$ on $V_{\mathrm{H}_{2} \mathrm{O}}$ set out in Fig. 10, shows that in all the cases within the graph there are three areas, which can be visually observed, where the correlations feature high degree of linearity in a certain range. In order to determine the boundaries of these almost linear sections, where the impact of $V_{\mathrm{H}_{2} \mathrm{O}}$ values on $V_{\text {oil }}$ is relatively homogenous, we will use the linear discriminant analysis [37-41].

Example of plotting the linear discriminant function for Wells 403 and 407:

$$
Z_{1}=-0.000146 V_{\mathrm{H}_{2} \mathrm{O}}-0.001917 V_{\text {oil }}+9.669477
$$

with $R=0.943, \chi^{2}=643.21, p=0.000000$;
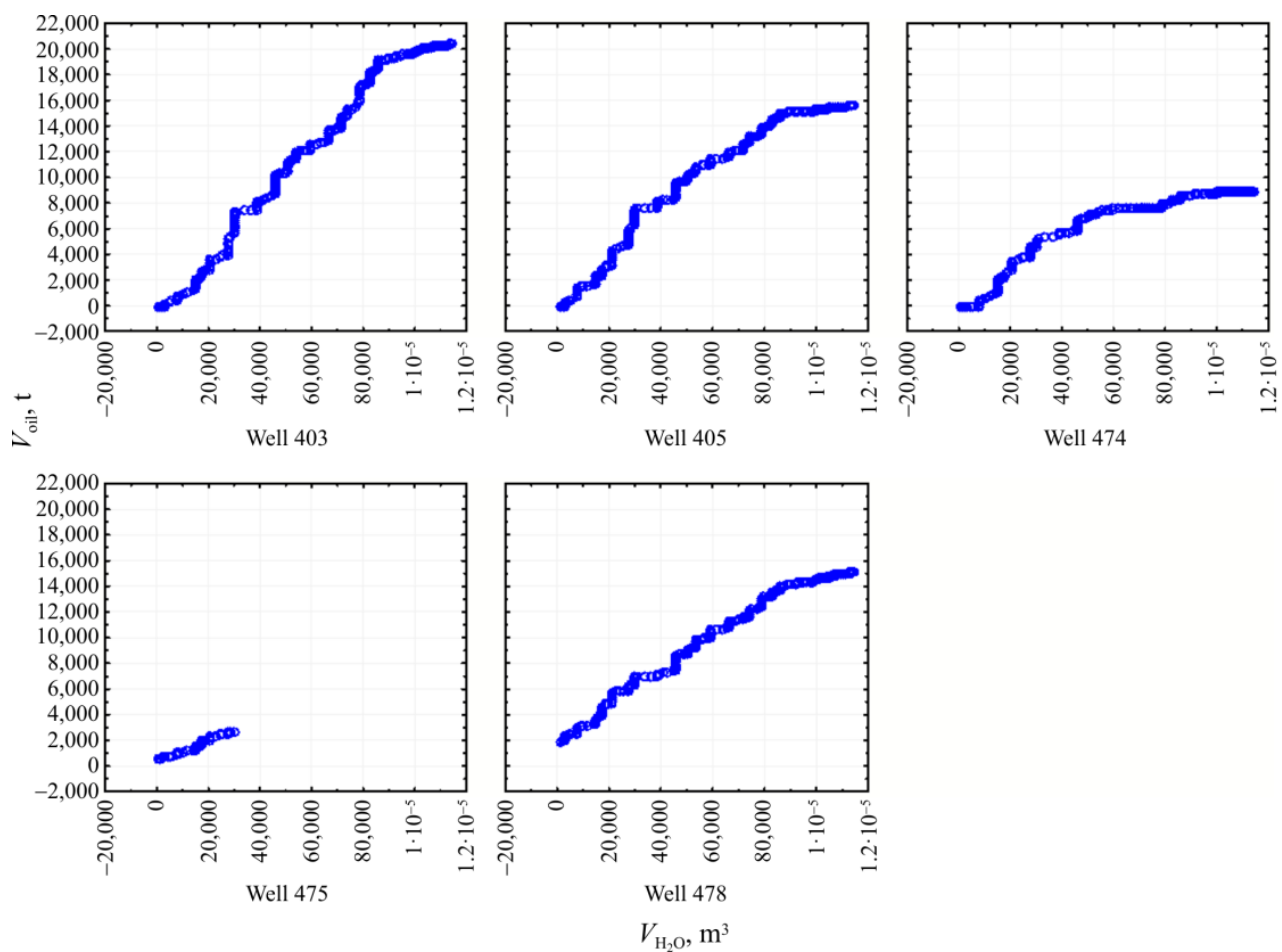

Fig. 10. Change in $V_{\text {oil }}$ values depending on $V_{\mathrm{H}_{2} \mathrm{O}}$ by well 


$$
Z_{2}=-0.00024 V_{\mathrm{H}_{2} \mathrm{O}}+0.0018 V_{\text {oil }}-3.54019
$$

with $R=0.338, \chi^{2}=31.74, p=0.000000$, where $V_{\text {oil }}$ is the volume of accumulated oil, tons $\left(Q_{\text {oil }}\right.$ accumulated, tons) and $V_{\mathrm{H}_{2} \mathrm{O}}$ is the accumulated injection volume $\left(Q_{\text {injection }}\right.$ accumulated, $\left.\mathrm{m}^{3}\right)$.

Based on these functions, the values $Z_{1}$ and $Z_{2}$ were calculated, and they were further used to determine the boundaries of classes in respect of the ratio of $V_{\text {oil }}$ to $V_{\mathrm{H}_{2} \mathrm{O}}$.

The first boundary has the value of $V_{\mathrm{H}_{2} \mathrm{O}}=$ $30,187 \mathrm{~m}^{3}$, the second $=71,595 \mathrm{~m}^{3}$. Using these boundaries, we have composed regression equations for the dependence of $V_{\text {oil }}$ on $V_{\mathrm{H}_{2} \mathrm{O}}$ (see Table 4). LDFs were also plotted for other wells, which were used to determine the classes' boundaries for the dependence of $V_{\text {oil }}$ on $V_{\mathrm{H}_{2} \mathrm{O}}$ within which regression equations were composed (see Table 2).

Table 4

Assessment of impact of $V_{\mathrm{H}_{2} \mathrm{O}}$ in the injection well 407 on $V_{\text {oil }}$ in producing wells 403 , $405,474,475,478$

\begin{tabular}{|l|c|c|c|}
\hline $\begin{array}{c}\text { Interval of values } \\
V_{\mathrm{H}_{2} \mathrm{O}}, \mathrm{m}^{3}\end{array}$ & Constant & Slope term & $\begin{array}{c}\text { Correlation } \\
\text { ratio } r\end{array}$ \\
\hline \multicolumn{4}{|c|}{ Well 403 } \\
\hline $0-30,187$ & -839.435 & 0.191 & 0.978 \\
\hline $30,187-71,595$ & 991.844 & 0.189 & 0.980 \\
\hline Over 71,595 $5,703.416$ & 0.139 & 0.911 \\
\hline \multicolumn{4}{|c|}{ Well 405 } \\
\hline $0-27,569$ & -582.34 & 0.197 & 0.978 \\
\hline $27,569-63,580$ & $1,752.795$ & 0.161 & 0.976 \\
\hline Over 63,580 & $6,764.785$ & 0.085 & 0.918 \\
\hline \multicolumn{4}{|c|}{ Well 474 } \\
\hline $0-20,873$ & -835.455 & 0.1745 & 0.956 \\
\hline $20,873-68,849$ & $1,941.655$ & 0.093 & 0.961 \\
\hline Over 68,849 $4,972.493$ & 0.038 & 0.945 \\
\hline \multicolumn{4}{|c|}{ Well 475 } \\
\hline $0-5,630$ & 567.945 & 0.045 & 0.858 \\
\hline $5,630-17,088$ & 369.914 & 0.069 & 0.942 \\
\hline Over 17,088 & 913.695 & 0.059 & 0.957 \\
\hline \multicolumn{4}{|c|}{ Well 478 } \\
\hline $0-17,088$ & $1,762.347$ & 0.128 & 0.959 \\
\hline $17,088-53,669$ & $2,861.668$ & 0.117 & 0.972 \\
\hline Over 53,669 & $4,788.573$ & 0.098 & 0.966 \\
\hline
\end{tabular}

It can be seen that the impact of $V_{\mathrm{H}_{2} \mathrm{O}}$ on $V_{\text {oil }}$ of Well 407 is different in the highlighted intervals. We note that for wells 403, 405, 474, 478 the minimum impact is observed in the third interval (minimal slope term) and maximum - in the first. For well 475 , the minimum impact is observed in the first interval, and maximum - in the second.

The graph showing the changes of $V_{\text {нерти }}$ values depending on the value of $V_{\mathrm{H}_{2} \mathrm{O}}$ in the third interval is shown in Fig. 11.

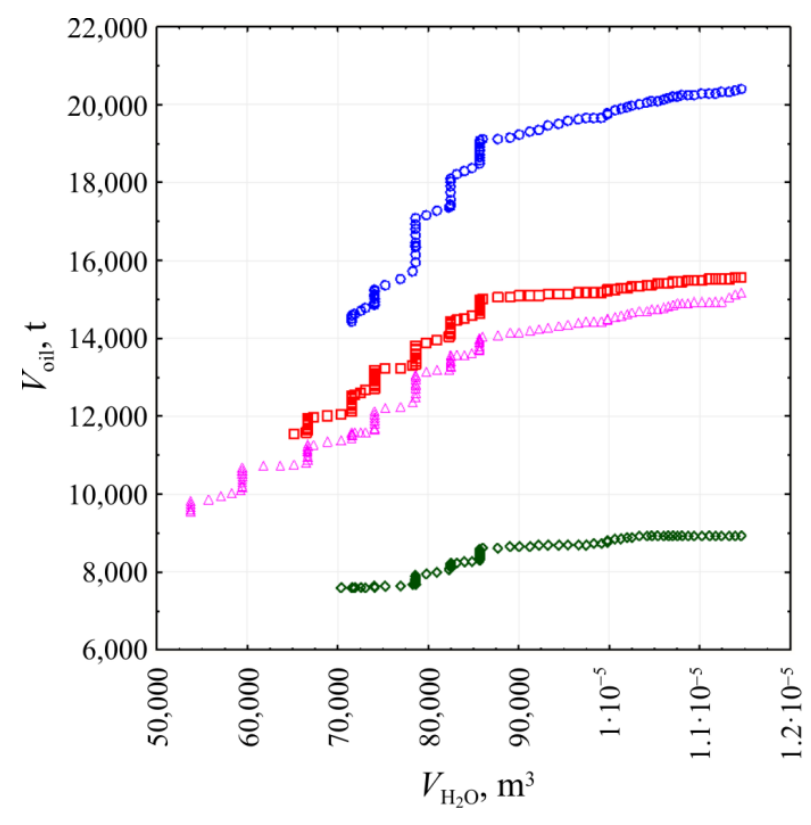

$\circ$ Well $403 \square$ Well $405 \diamond$ Well $474 \Delta$ Well 478

Fig. 11. Change in the values of $V_{\text {oil }}$ depending on $V_{\mathrm{H}_{2} \mathrm{O}}$ in the third interval

Regression equations between injection well 407 and producing wells:

Well 403: $V_{\text {oil }}=5,703.4162+0.139 V_{\mathrm{H}_{2} \mathrm{O}}$;

Well 405: $V_{\text {oil }}=6,764.7847+0.0845 V_{\mathrm{H}_{2} \mathrm{O}}$;

Well 474: $V_{\text {oil }}=4,972.4927+0.0377 V_{\mathrm{H}_{2} \mathrm{O}}$;

Well 478: $V_{\text {oil }}=4,788.5732+0.0977 V_{\mathrm{H}_{2} \mathrm{O}}$.

Having analyzed the obtained graph and regression equation, we can say that the highest slope term is featured by Well $403(0.139)$ and the lowest - by Well 474 (0.0377). The slope term of other wells ranges from 0.0845 to 0.0977 .

The method of assessing the impact of water injection into the formation on oil production for Well 424. The method of assessing the impact of water injection into the formation on the production of oil uses the information on Well 424 for the period from August, 1993, to February, 2016 , i.e. for 271 months $(n=271)$.

On the basis of this information we will assess the impact of the monthly volume of water injected into the formation $V_{\mathrm{H}_{2} \mathrm{O}}^{\mathrm{m}}$ on the monthly oil production $V_{\text {oil }}^{\mathrm{m}}$. 


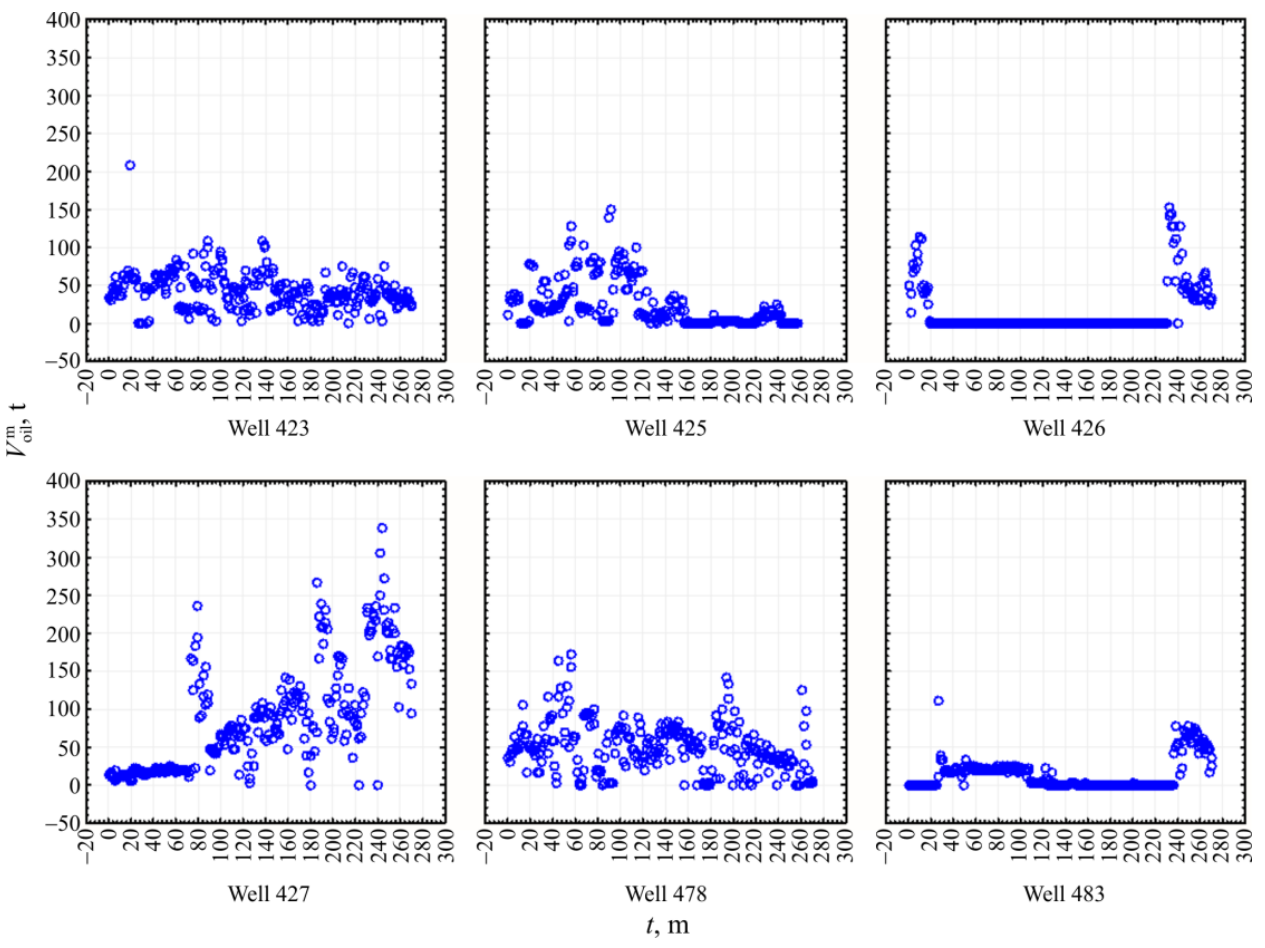

Fig. 12. Change of values of $V_{\text {oil }}^{\mathrm{m}}$ in time $t$ by wells

For the purposes of the method development, the values of $V_{\mathrm{H}_{2} \mathrm{O}}^{\mathrm{m}}$ for the injection wells located in different reservoir areas were used. We assume that the injection of water into this well will have an impact on the monthly production of oil by wells 210, 423, 425, 427, 478, 483.

The change of values of $V_{\text {oil }}^{\mathrm{m}}$ is time $t$ is shown in Fig. 12.

It is seen that the values of $V_{\text {oil }}^{\mathrm{m}}$, tons, vary significantly by well.

The change of values of $V_{\mathrm{H}_{2} \mathrm{O}}^{\mathrm{m}}$ in time for Well 424 is shown in Fig. 13.

The change of values of $V_{\mathrm{H}_{2} \mathrm{O}}^{\mathrm{m}}$ depending on $\mathrm{t}$ has quite a complex view.

In order to compare the values of $V_{\mathrm{H}_{2} \mathrm{O}}^{\mathrm{m}}$ and $V_{\text {oil }}^{\mathrm{m}}$ for the two reviewed options of impact of the injection wells, correlation plots set out in Fig. 14 were built for the injections wells.

The values of $V_{\mathrm{H}_{2} \mathrm{O}}^{\mathrm{m}}$ and $V_{\text {oil }}^{\mathrm{m}}$ have a weak correlation, i.e. it is impossible to prove in statistical terms the impact of $V_{\mathrm{H}_{2} \mathrm{O}}^{\mathrm{m}}$ values on $V_{\text {oil }}^{\mathrm{m}}$ values. Now we are going to prove this statement with the calculations of $r$ and composing regression equations. $V_{\text {oil }}^{\mathrm{m}}$ (oil production for a month, tonnes) will be a dependent attribute and $V_{\mathrm{H}_{2} \mathrm{O}}^{\mathrm{m}}$ (water injection into the formation for a month, $\mathrm{m}^{3}$ ) will be an independent factor.

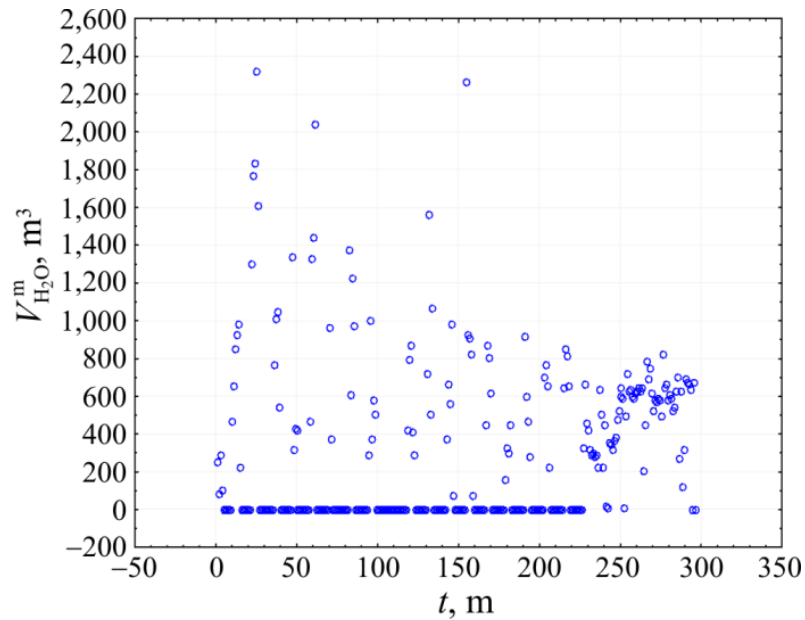

Fig. 13. Change of values of $V_{\mathrm{H}_{2} \mathrm{O}}^{\mathrm{m}}$ in time for Well 424

As a result of this method application, the values of $r$ were calculated and regression equations were made for the following options:

a) based on the information about each well;

b) based on the information about all the wells.

The values of $r$ and regression equations of $V_{\text {oil }}^{\mathrm{m}}$ dependence on $V_{\mathrm{H}_{2} \mathrm{O}}^{\mathrm{m}}$ in the above options are set out in Table 5. 


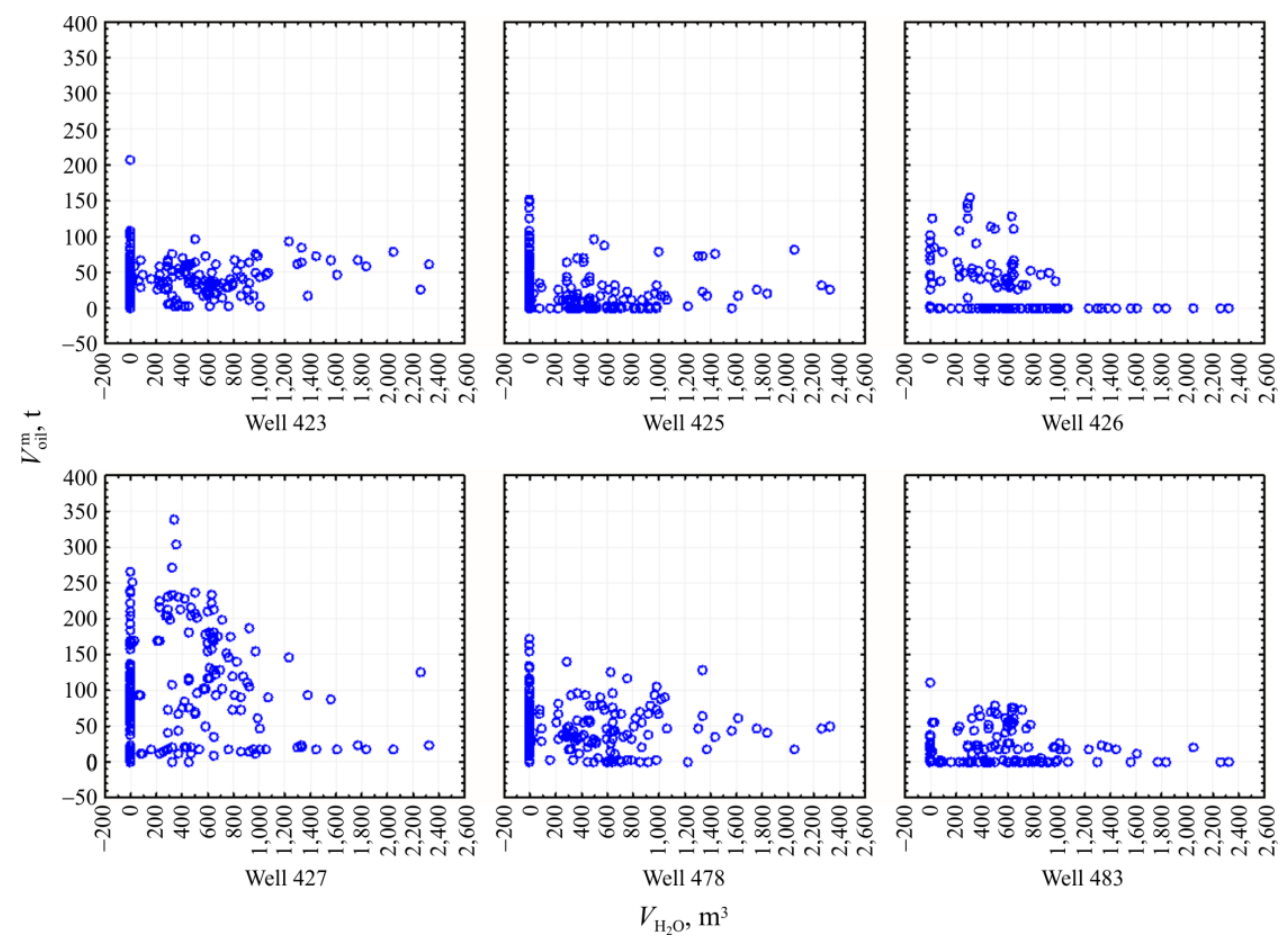

Fig. 14. Correlation plot of $V_{\mathrm{H}_{2} \mathrm{O}}^{\mathrm{m}}$ and $V_{\text {oil }}^{\mathrm{m}}$

Table 5 the dependence of impact rendered by the

Absolute and corner terms and correlation ratio of regression equation showing the dependence of $V_{\text {oil }}^{\mathrm{m}}$ on $V_{\mathrm{H}_{2} \mathrm{O}}^{\mathrm{m}}$ (upper line), dependence of $V_{\text {oil }}$ on $V_{\mathrm{H}_{2} \mathrm{O}}$ (lower line) for Well 424

\begin{tabular}{|c|c|c|c|}
\hline Well & Constant & Slope term & $\begin{array}{l}\text { Correlation } \\
\text { ratio } r\end{array}$ \\
\hline \multirow{2}{*}{423} & 41.059 & $\underline{0.0026}$ & $\underline{0.046}$ \\
\hline & $1,514.586$ & 0.162 & 0.993 \\
\hline \multirow{2}{*}{426} & $\underline{12.186}$ & $\underline{0.005}$ & $\underline{0.005}$ \\
\hline & $3, \overline{257.244}$ & $\overline{0.023}$ & $\overline{0.681}$ \\
\hline \multirow{2}{*}{483} & 12.946 & $\underline{0.005}$ & 0.104 \\
\hline & $\overline{643.638}$ & $\overline{0.042}$ & $\overline{0.941}$ \\
\hline \multirow{2}{*}{427} & 85.255 & 0.0128 & $\underline{0.079}$ \\
\hline & $-4,321.115$ & 0.337 & 0.957 \\
\hline \multirow{2}{*}{425} & $\underline{24.601}$ & -0.005 & -0.07 \\
\hline & $1,110.278$ & 0.108 & 0.937 \\
\hline \multirow{2}{*}{478} & $\underline{51.725}$ & -0.007 & -0.092 \\
\hline & $1,527.189$ & 0.199 & 0.994 \\
\hline \multirow{2}{*}{ All wells } & 38.205 & $\underline{0.003}$ & 0.0023 \\
\hline & $\overline{568.990}$ & $\overline{0.147}$ & $\overline{0.642}$ \\
\hline
\end{tabular}

The analysis of the values of constant and slope terms of a regression equation and $r$ ratio indicates that it is not possible to measure the impact of $V_{\mathrm{H}_{2} \mathrm{O}}^{\mathrm{m}}$ on $V_{\mathrm{oil}}^{\mathrm{m}}$ using the provided regression equations. This is especially evident if we look at very low values of $r$ ratios.

In order to assess the effectiveness of water injection into the formation, it is proposed to use accumulated volume of injected water $\left(V_{\mathrm{H}_{2} \mathrm{O}}\right)$ on the accumulated oil production $\left(V_{\text {oil }}\right)$ based on the information for 271 months.

The dependencies of $V_{\text {oil }}$ on $V_{\mathrm{H}_{2} \mathrm{O}}$ for the wells under review are shown in Fig. 15.

It can be seen that as opposed to the previous graphs, in Fig. 15 when the values of $V_{\mathrm{H}_{2} \mathrm{O}}$ increase, the values of $V_{\text {oil }}$ also go up, however, the gradients are individual for each well. The values of $r$ and regression equations of $V_{\text {oil }}$ on $V_{\mathrm{H}_{2} \mathrm{O}}$ are set out in Table 6 . The values of $r$ are high for all the wells and statistically significant by $t$ criteria, which may indicate an actual impact of $V_{\mathrm{H}_{2} \mathrm{O}}$ on $V_{\text {oil }}$ across all the wells.

The analysis of dependencies of $V_{\text {oil }}$ on $V_{\mathrm{H}_{2} \mathrm{O}}$ set out in Fig. 15, shows that in all the cases within the graph there are three areas, which can be visually observed, where the correlations feature in a certain range high degree of linearity. In order to determine the boundaries of these almost linear sections, where the impact of $V_{\mathrm{H}_{2} \mathrm{O}}$ values on $V_{\text {oil }}$ is relatively homogenous, we will use the linear discriminant analysis. 


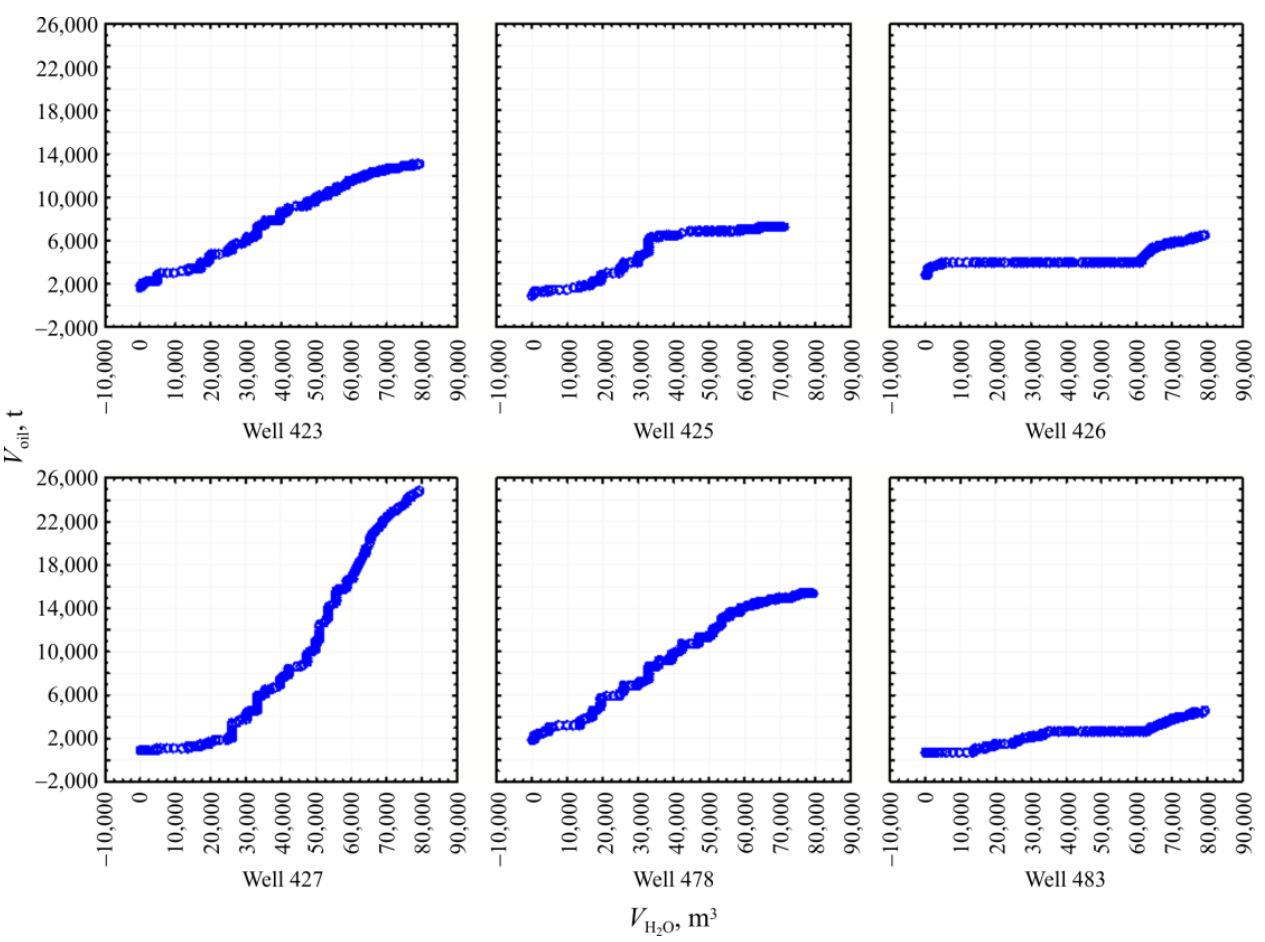

Fig. 15. Change of $V_{\text {oil }}$ values depending on $V_{\mathrm{H}_{2} \mathrm{O}}$ by wells

Example of plotting the linear discriminant function for Wells 423 and 424:

$$
Z_{1}=-0.000208 V_{\mathrm{H}_{2} \mathrm{O}}+0.000728 V_{\text {oil }}+5.89479
$$

with $R=0.943, \chi^{2}=707.431, p=0.000000$;

$$
Z_{2}=-0.0005 V_{\mathrm{H}_{2} \mathrm{O}}+0.00285 V_{\text {oil }}-2.87433
$$

with $R=0.679, \chi^{2}=165.59, p=0.000000$.

Based on these functions, the values $Z_{1}$ and $Z_{2}$ were calculated, and they were further used to determine the boundaries of classes in respect of the ratio of $V_{\text {oil }}$ to $V_{\mathrm{H}_{2} \mathrm{O}}$.

Close to the first boundary, $V_{\mathrm{H}_{2} \mathrm{O}}=33,029 \mathrm{~m}^{3}$, and close to the second boundary - to $71,261 \mathrm{~m}^{3}$.

Using these boundaries, we have composed regression equations in respect of dependence of $V_{\text {oil }}$ on $V_{\mathrm{H}_{2} \mathrm{O}}$. LDFs were also plotted for other wells, which were used to determine the classes' boundaries for the dependence of $V_{\text {oil }}$ on $V_{\mathrm{H}_{2} \mathrm{O}}$. within which regression equations were composed (see Table 6).

It can be seen that the impact of $V_{\mathrm{H}_{2} \mathrm{O}}$ on $V_{\text {oil }}$ of Well 424 is different in the highlighted intervals. We note that the minimum impact is observed in the first interval for Wells 427 and 483 , and in the third interval - for Wells 423, 425 and 478, in the second - for Well 426

Table 6 Assessment of impact of $V_{\mathrm{H}_{2} \mathrm{O}}$ in injection well 424 on $V_{\text {oil }}$ in producing wells 423 ,

\begin{tabular}{|c|c|c|c|}
\hline $\begin{array}{l}\text { Interval of values } \\
\qquad V_{\mathrm{H}_{2} \mathrm{O}}, \mathrm{m}^{3}\end{array}$ & Constant & Slope term & $\begin{array}{l}\text { Correlation } \\
\quad \text { ratio } r\end{array}$ \\
\hline \multicolumn{4}{|c|}{ Well 423} \\
\hline $0-33,029$ & $1,670.640$ & 0.142 & 0.983 \\
\hline $33,029-71,261$ & $2,232.123$ & 0.152 & 0.995 \\
\hline Over 71,261 & $8,735.536$ & 0.055 & 0.997 \\
\hline \multicolumn{4}{|c|}{ Well 425} \\
\hline $0-30,293$ & 730.656 & 0.102 & 0.949 \\
\hline $30,293-49,389$ & $2,333.654$ & 0.101 & 0.828 \\
\hline Over 49,389 & $5,763.419$ & 0.0213 & 0.961 \\
\hline \multicolumn{4}{|c|}{ Well 426} \\
\hline $0-722$ & $2,627.573$ & 0.730 & 0.612 \\
\hline $722-63,501$ & $3,850.544$ & 0.002 & 0.376 \\
\hline Over 63,501 & -609.562 & 0.09 & 0.979 \\
\hline \multicolumn{4}{|c|}{ Well 427} \\
\hline $0-13,643$ & 881.735 & 0.026 & 0.968 \\
\hline $13,643-53,500$ & $-4,865.397$ & 0.31 & 0.984 \\
\hline Over 53,500 & $-10,613.584$ & 0.462 & 0.991 \\
\hline \multicolumn{4}{|c|}{ Well 478} \\
\hline $0-22,736$ & $1,947.028$ & 0.149 & 0.941 \\
\hline $22,736-69,281$ & 973.125 & 0.215 & 0.993 \\
\hline Over 69,281 & $10,638.89$ & 0.06 & 0.942 \\
\hline \multicolumn{4}{|c|}{ Well 483} \\
\hline $0-24,779$ & 492.676 & 0,041 & 0.933 \\
\hline $24,779-68,189$ & $1,661.532$ & 0,02 & 0.806 \\
\hline Over 68,189 & $-2,481.698$ & 0,09 & 0.992 \\
\hline
\end{tabular}
$425,426,427,478,483$ 
(minimum slope term). The maximum impact is observed in the first interval for Wells 425 and 426, in the second - for Wells 427 and 483 (maximum slope term).

The graph showing the changes of $V_{\text {oil }}$ values depending on the value of $V_{\mathrm{H}_{2} \mathrm{O}}$ in the third interval is shown in Fig. 16.

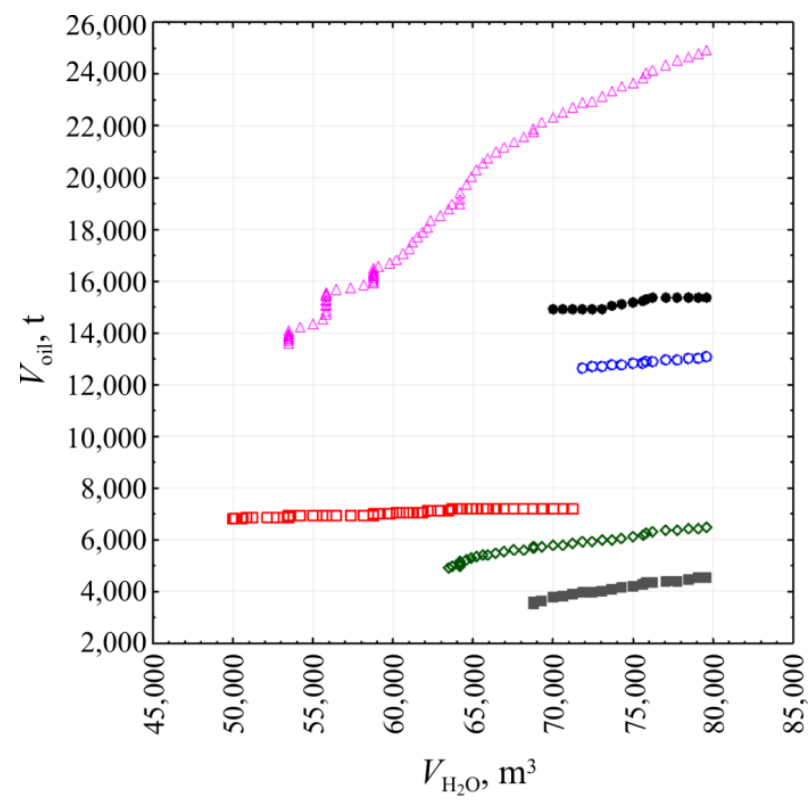

○ Well $423 \square$ Well $425 \diamond$ Well 426

$\triangle$ Well $427 \bullet$ Well 478 • Well 483

Fig. 16. Change in the values of $V_{\text {oil }}$ depending on $V_{\mathrm{H}_{2} \mathrm{O}}$ in the third interval
Regression equations between injection well 424 and producing wells:

Well 423: $V_{\text {oil }}=8,735.5356+0.0545 V_{\mathrm{H}_{2} \mathrm{O}}$;

Well 425: $V_{\text {oil }}=5,763.4186+0.0213 V_{\mathrm{H}_{2} \mathrm{O}}$;

Well 426: $V_{\text {oil }}=-609.5622+0.0905 V_{\mathrm{H}_{2} \mathrm{O}}$;

Well 427: $V_{\text {oil }}=-10,613.5839+0.4615 V_{\mathrm{H}_{2} \mathrm{O}}$;

Well 478: $V_{\text {oil }}=10,638.8898+0.0604 V_{\mathrm{H}_{2} \mathrm{O}}$;

Well 483: $V_{\text {oil }}=-2,481.6977+0.0891 V_{\mathrm{H}_{2} \mathrm{O}}$.

Having analyzed the obtained graph and regression equation, we can say that the highest slope term is featured by Well $427(0.4615)$ and the lowest - by Well 425 (0.0213). The slope term of other wells ranges from 0.0545 to 0.0905 .

The method of assessing the impact of water injection into the formation on oil production for Well 472. The method of assessing the impact of water injection into the formation on the production of oil uses the information on the Well 472 for the period from July, 1993, to February, 2015, i.e. for 260 months $(n=260)$.

On the basis of this information, we have assessed the impact of the monthly volume of water injected into the formation $V_{\mathrm{H}_{2} \mathrm{O}}^{\mathrm{m}}$ on the monthly oil production $V_{\text {oil }}^{\mathrm{m}}$.

For the purposes of the method development, the values of $V_{\mathrm{H}_{2} \mathrm{O}}^{\mathrm{m}}$ for the injection wells located in different reservoir areas were used. We assume that the injection of water into this well will have
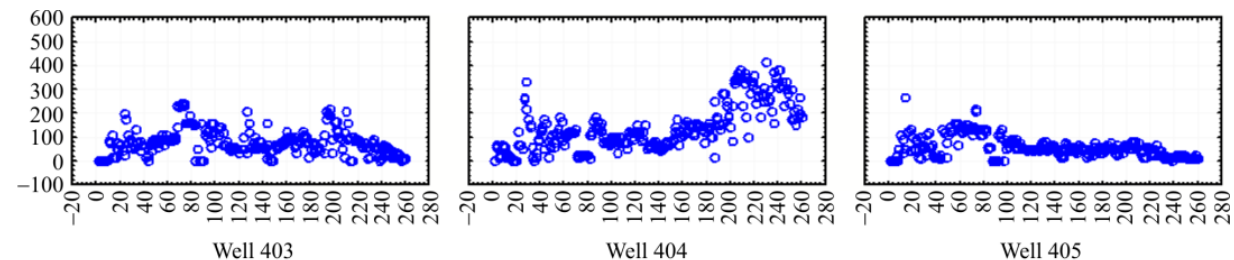

Well 403

Well 404

Well 405
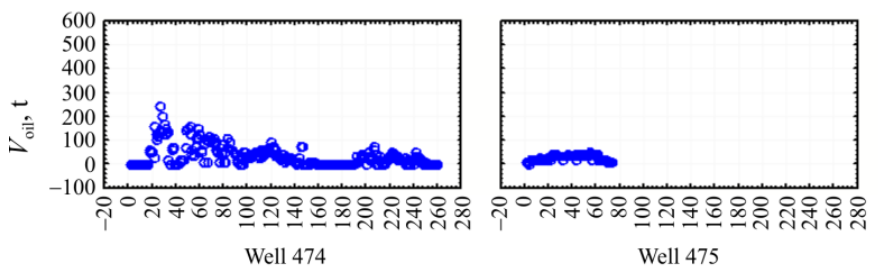

Well 475

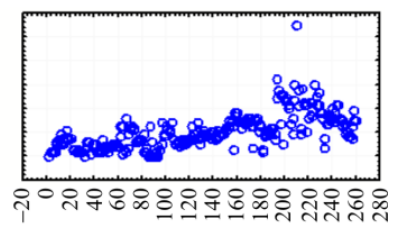

Well 477

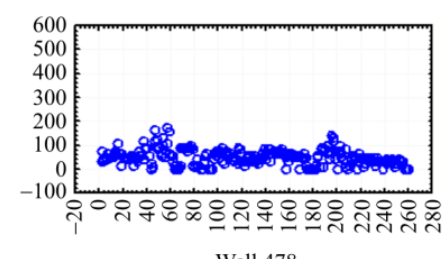

Well 478

$t, \mathrm{~m}$

Fig. 17. Change of values of $V_{\text {oil }}^{\mathrm{m}}$ in time $t$ by wells 

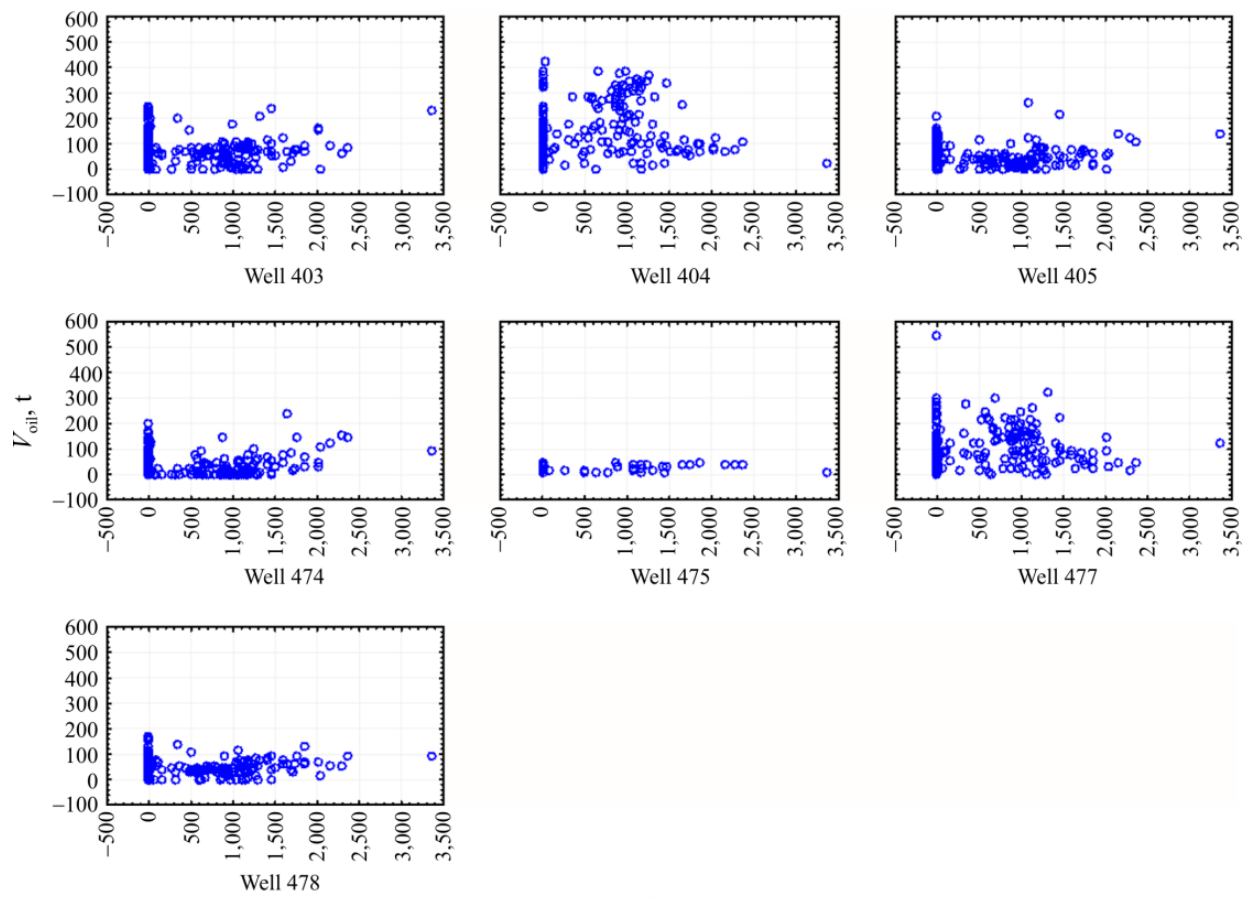

$V_{\mathrm{H}_{2} \mathrm{O}}^{\mathrm{m}}, \mathrm{m}^{3}$

Fig. 19. Field of correlation between $V_{\mathrm{H}_{2} \mathrm{O}}^{\mathrm{m}}$ and $V_{\text {oil }}^{\mathrm{m}}$

an impact on the monthly production of oil by wells 403-405, 474, 475, 477, 478. The change of values of $V_{\text {oil }}^{\mathrm{m}}$ is time $\mathrm{t}$ is shown in Fig. 17.

The analysis of Fig. 17 shows that the values of $V_{\text {oil }}^{\mathrm{m}}$ by wells differ materially.

The change of values of $V_{\mathrm{H}_{2} \mathrm{O}}^{\mathrm{m}}$ in time for Well 424 is shown in Fig. 18.

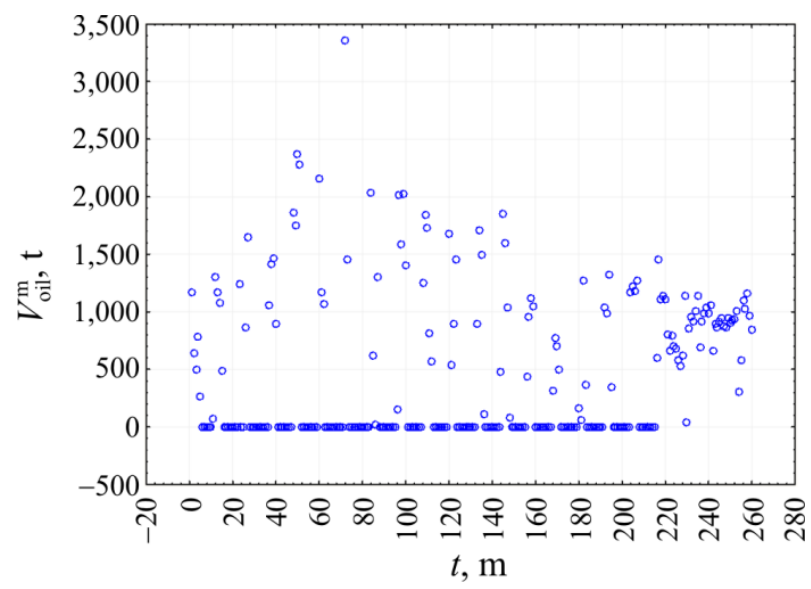

Fig. 18. Change of values of $V_{\mathrm{H}_{2} \mathrm{O}}^{\mathrm{m}}$ in time for Well 472

The change of values of $V_{\mathrm{H}_{2} \mathrm{O}}^{\mathrm{m}}$ depending on $t$ has quite a complex view.

In order to compare the values of $V_{\mathrm{H}_{2} \mathrm{O}}^{\mathrm{m}}$ and $V_{\text {oil }}^{\mathrm{m}}$ for the two reviewed options of impact of the injection wells, correlation fields set out in Fig. 19 were built for the injections wells.

The values of $V_{\mathrm{H}_{2} \mathrm{O}}^{\mathrm{m}}$ and $V_{\text {oil }}^{\mathrm{m}}$ have a weak correlation, i.e. it is impossible to prove in statistical terms the impact of $V_{\mathrm{H}_{2} \mathrm{O}}^{\mathrm{m}}$ values on $V_{\text {oil }}^{\mathrm{m}}$ values. Now we are going to prove this statement with the calculations of $\mathrm{r}$ and making regression equations. We will take $V_{\text {oil }}^{\mathrm{m}}$, as a slope term and $V_{\mathrm{H}_{2} \mathrm{O}}^{\mathrm{m}}$ as a constant.

As a result of this method application, the values of $r$ were calculated and regression equations were made for the following options:

a) based on the information about each well;

b) based on the information about all the wells.

The values of $r$ and regression equations of $V_{\text {oil }}^{\mathrm{m}}$ dependence on $V_{\mathrm{H}_{2} \mathrm{O}}^{\mathrm{m}}$ in the above options are set out in Table 7.

The analysis of the values of constant and slope terms of a regression equation and $r$ ratio indicates that it is not possible to measure the impact of $V_{\mathrm{H}_{2} \mathrm{O}}^{\mathrm{m}}$ on $V_{\text {oil }}^{\mathrm{m}}$ using the provided regression equations. This is especially evident if we look at very low values of $r$ ratios.

In order to assess the effectiveness of water injection into the formation, it is suggested to use the following dependencies 
Table 7

Absolute and corner terms and correlation ratio of regression equation showing the dependence of $V_{\text {oil }}^{\mathrm{m}}$ on $V_{\mathrm{H}_{2} \mathrm{O}}^{\mathrm{m}}$ (upper line), dependence of $V_{\text {oil }}$ on $V_{\mathrm{H}_{2} \mathrm{O}}$ (lower line) for Well 472

\begin{tabular}{|c|c|c|c|}
\hline Well & Constant & Slope term & $\begin{array}{l}\text { Correlation } \\
\text { ratio } r\end{array}$ \\
\hline 403 & $\frac{81.348}{-519.835}$ & $\frac{0.007}{0.204}$ & $\frac{-0.083}{0.988}$ \\
\hline 404 & $\underline{-3,658.375}$ & $\frac{0.026}{0.315}$ & $\frac{0.167}{0.974}$ \\
\hline 405 & $\frac{64.540}{1,023.096}$ & $\frac{-0.011}{0.151}$ & $\frac{-0.151}{0.974}$ \\
\hline 474 & $\frac{29.808}{1,345.355}$ & $\underline{0.01}$ & $\frac{0.146}{0.938}$ \\
\hline 475 & $\frac{26.884}{501.645}$ & $\underline{0.001}$ & $\underline{0.066}$ \\
\hline 477 & $\frac{100.175}{-3,635.677}$ & $\underline{0.006}$ & $\underline{0.046}$ \\
\hline 478 & $2, \frac{50.446}{306.813}$ & $\frac{-0.00006}{0.124}$ & $\frac{-0.001}{0.988}$ \\
\hline All wells & $\frac{54.647}{741.962}$ & $\frac{-0.004}{0.148}$ & $\frac{-0.048}{0.888}$ \\
\hline
\end{tabular}

of impact of the accumulated water injection volume $\left(V_{\mathrm{H}_{2} \mathrm{O}}\right)$ on the accumulated oil production volume $\left(V_{\text {oil }}\right)$ based on the information for 260 months. The dependencies of $V_{\text {oil }}$ on $V_{\mathrm{H}_{2} \mathrm{O}}$ for the wells under review are shown in Fig. 20.
It can be seen that as opposed to the previous graphs, in Fig. 20 when the values of $V_{\mathrm{H}_{2} \mathrm{O}}$ increase, the values of $V_{\text {oil }}$ also go up, however, the gradients are individual for each well. The values of $\mathrm{r}$ and regression equations of $V_{\text {oil }}$ on $V_{\mathrm{H}_{2} \mathrm{O}}$ are set out in Table 8. The values of $r$ are high for all the wells and statistically significant by $t$ criteria, which may indicate an actual impact of $V_{\mathrm{H}_{2} \mathrm{O}}$ on $V_{\text {oil }}$ across all the wells.

The analysis of dependencies of $V_{\text {oil }}$ on $V_{\mathrm{H}_{2} \mathrm{O}}$ set out in Fig. 20, shows that in all the cases within the graph there are three areas, which can be visually observed, where the correlations feature in a certain range high degree of linearity. In order to determine the boundaries of these almost linear sections, where the impact of $V_{\mathrm{H}_{2} \mathrm{O}}$ values on $V_{\text {oil }}$ is relatively homogenous, we will use the linear discriminant analysis.

Example of plotting the linear discriminant function for Wells 403 and 472:

$$
Z_{1}=-0.00023 V_{\mathrm{H}_{2} \mathrm{O}}+0.000941 V_{\text {oil }}+3.899984
$$

with $R=0.942, \chi^{2}=760.4577, p=0.000000$;

$$
Z_{2}=0.000174 V_{\mathrm{H}_{2} \mathrm{O}}-0.001254 V_{\text {oil }}+2.145452
$$

with $R=0.732, \chi^{2}=196.9258, p=0.000000$.
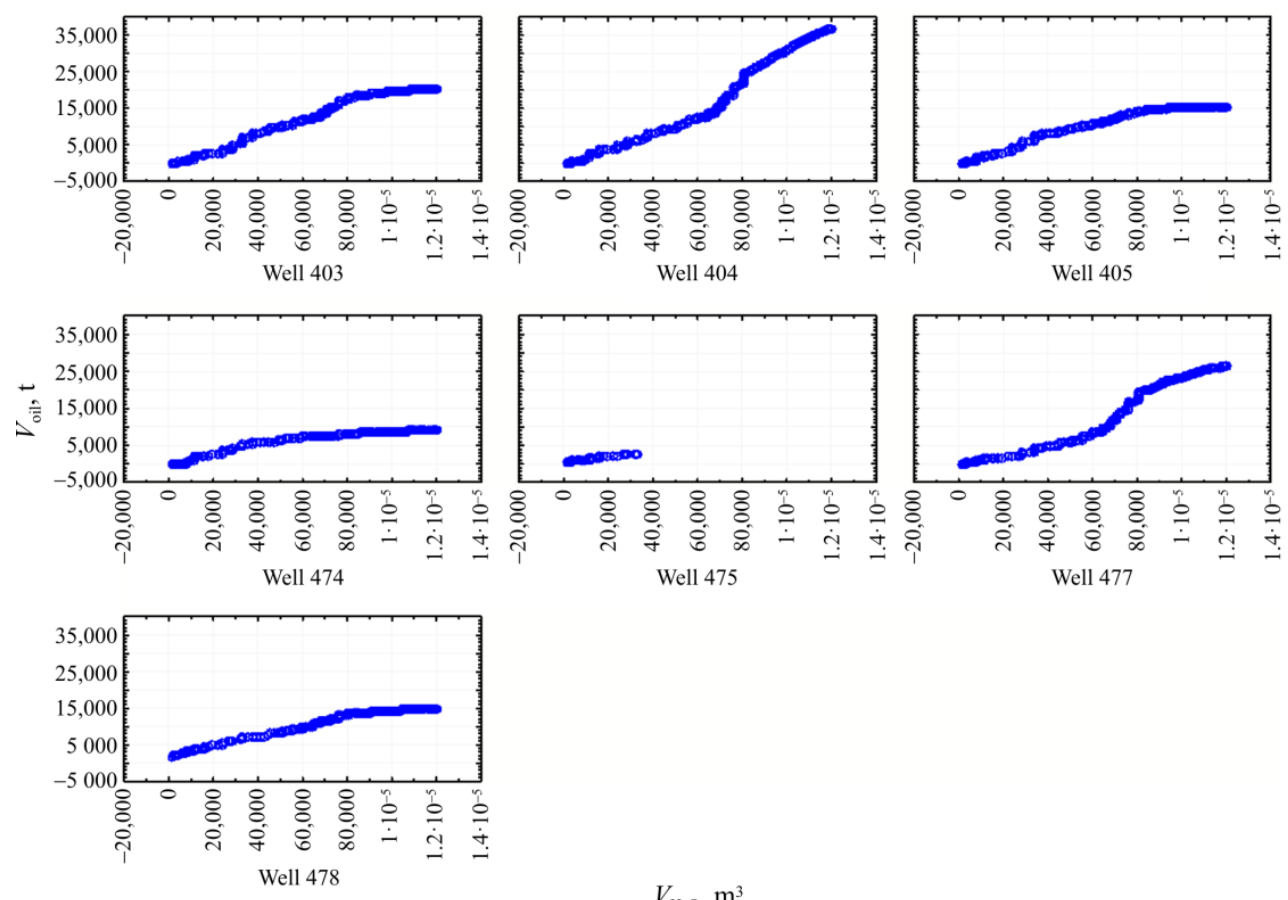

$$
V_{\mathrm{H}_{2} \mathrm{O}}, \mathrm{m}^{3}
$$

Fig. 20. Change in $V_{\text {oil }}$ values depending on $V_{\mathrm{H}_{2} \mathrm{O}}$ by well 
Based on these functions, the values $Z_{1}$ and $Z_{2}$ were calculated, and they were further used to determine the boundaries of classes in respect of the ratio of $V_{\text {oil }}$ to $V_{\mathrm{H}_{2} \mathrm{O}}$.

The first boundary has the value of $V_{\mathrm{H}_{2} \mathrm{O}}=$ $=33,029 \mathrm{~m}^{3}$, the second - of $71,595 \mathrm{~m}^{3}$. Using this information, we have composed regression equations for the dependence of $V_{\text {oil }}$ on $V_{\mathrm{H}_{2} \mathrm{O}}$ (see Table 8). LDFs were also plotted for other wells, which were used to determine the classes' boundaries for the dependence of $V_{\text {oil }}$ on $V_{\mathrm{H}_{2} \mathrm{O}}$ within which regression equations were composed.

Table 8

Assessment of impact of $V_{\mathrm{H}_{2} \mathrm{O}}$ in injection well 472 on $V_{\text {oil }}$ in producing wells 403-405, $474,475,477,478$

\begin{tabular}{|c|c|c|c|}
\hline $\begin{array}{l}\text { Interval of values } \\
\qquad V_{\mathrm{H}_{2} \mathrm{O}}, \mathrm{m}^{3}\end{array}$ & Constant & Slope term & $\begin{array}{l}\text { Correlation } \\
\quad \text { ratio } r\end{array}$ \\
\hline \multicolumn{4}{|c|}{ Well 403} \\
\hline $0-45,932$ & $-1,087.158$ & 0.221 & 0.980 \\
\hline $45,932-100,403$ & $-2,016.843$ & 0.232 & 0.979 \\
\hline Over 100,403 & $16,070.244$ & 0.036 & 0.973 \\
\hline \multicolumn{4}{|c|}{ Well 404} \\
\hline $0-39,673$ & -581.660 & 0.215 & 0.989 \\
\hline $39,673-80,967$ & $-7,428.683$ & 0.339 & 0.957 \\
\hline Over 80,967 & $-3,801.333$ & 0.346 & 0.995 \\
\hline \multicolumn{4}{|c|}{ Well 405} \\
\hline $0-45,932$ & -609.042 & 0.212 & 0.988 \\
\hline $45,932-95,653$ & $1,784.522$ & 0.150 & 0.985 \\
\hline Over 95,653 & $13,354.822$ & 0.018 & 0.994 \\
\hline \multicolumn{4}{|c|}{ Well 474} \\
\hline $0-41,258$ & -571.296 & 0.162 & 0.987 \\
\hline $41,258-88,637$ & $3,863.416$ & 0.053 & 0.956 \\
\hline Over 88,637 & $7,274.674$ & 0.015 & 0.967 \\
\hline \multicolumn{4}{|c|}{ Well 475} \\
\hline $0-11,236$ & 491.402 & 0.064 & 0.963 \\
\hline $11,236-19,679$ & 602.126 & 0.072 & 0.939 \\
\hline Over 19,679 & 723.364 & 0.062 & 0.894 \\
\hline \multicolumn{4}{|c|}{ Well 477} \\
\hline $0-68,288$ & -859.575 & 0.149 & 0.981 \\
\hline $68,288-80,967$ & $\begin{array}{c}- \\
24,166.504\end{array}$ & 0.522 & 0.969 \\
\hline Over 80,967 & $2,835.772$ & 0.204 & 0.986 \\
\hline \multicolumn{4}{|c|}{ Well 478} \\
\hline $0-39,673$ & $1,785.563$ & 0.145 & 0.996 \\
\hline $39,673-98,498$ & $1,065.275$ & 0.146 & 0.984 \\
\hline Over 98,498 & $11,398.578$ & 0.03 & 0.985 \\
\hline
\end{tabular}

It can be seen that the impact of $V_{\mathrm{H}_{2} \mathrm{O}}$ on $V_{\text {oil }}$ of Well 424 is different in the highlighted intervals. We note that for wells 403, 405, 474, 475 and 478 the minimum impact is observed in the third interval (minimal slope term) and maximum - in the second. For Well 404, the minimum impact is observed in the first interval, and maximum - in the third. For Well 477, the impact is maximum in the second interval and minimum - in the first.

The graph showing the changes of $V_{\text {oil }}$ values depending on the value of $V_{\mathrm{H}_{2} \mathrm{O}}$ in the third interval is shown in Fig. 21.

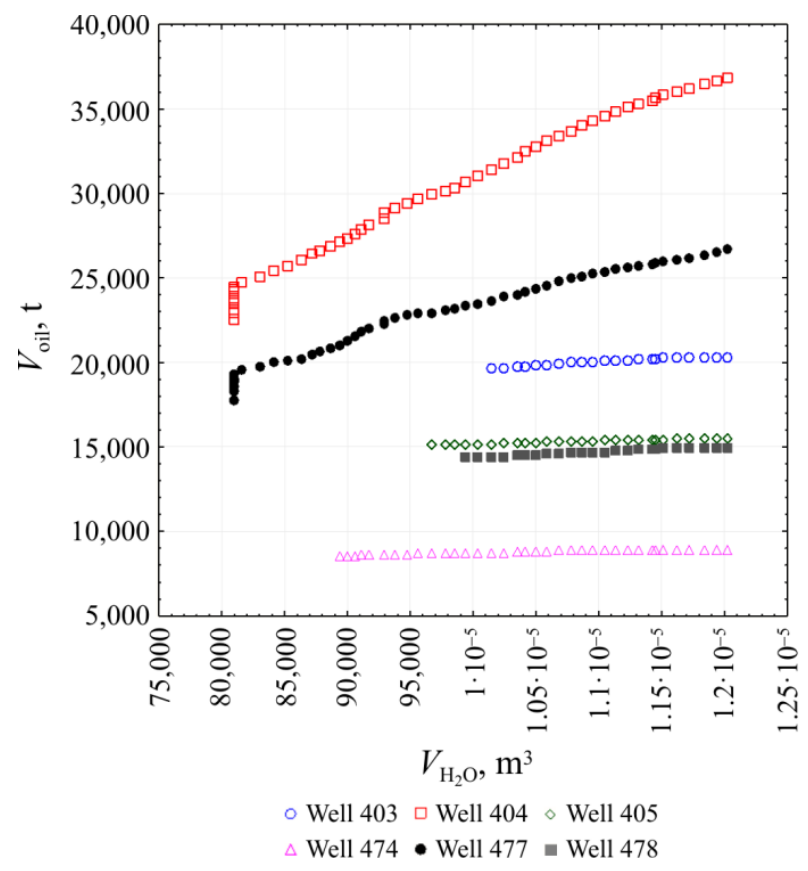

Fig. 21. Change in the values of $V_{\text {oil }}$ depending on $V_{\mathrm{H}_{2} \mathrm{O}}$ in the third interval

Regression equations between injection well 472 and producing wells:

Well 403: $V_{\text {oil }}=16,070.2439+0.0359 V_{\mathrm{H}_{2} \mathrm{O}}$;

Well 404: $V_{\text {oil }}=-3,801.3332+0.3456 V_{\mathrm{H}_{2} \mathrm{O}}$;

Well 405: $V_{\text {oil }}=13,354.8221+0.0182 V_{\mathrm{H}_{2} \mathrm{O}}$;

Well 474: $V_{\text {oil }}=7,274.674+0.0146 V_{\mathrm{H}_{2} \mathrm{O}}$;

Well 477: $V_{\text {oil }}=2,835.7721+0.2035 V_{\mathrm{H}_{2} \mathrm{O}}$;

Well 478: $V_{\text {oil }}=11,398.5776+0.03 V_{\mathrm{H}_{2} \mathrm{O}}$.

Having analyzed the obtained graph and regression equation, we can say that the highest slope term is featured by Well $404(0.3456)$ and the lowest - by Well 474 (0.0146). The slope term of other wells ranges from 0.0182 to 0.2035 .

As a result of the performed research the following recommendations may be formulated for 
the optimization of oil production from $\mathrm{T}_{1}$ of Sosnovskoe oilfield.

13 production enhancement operations were performed in respect of producing well pool for 1997-2014. The leading technology in terms of implementation volume is the formation reperforation with further treatment of wellbore area with acid agent preventing emulsification (four recovery enhancement operations were performed, average initial growth amounted to 4.9 tonnes/day with specific incremental production of 2,529.6 tonnes). Besides, one recovery enhancement operation was carried out according to hydroacoustic effect technology (initial growth amounted to 5.0 tonnes per day with the specific incremental production of 1,286.9 tonnes).

The highest efficiency in terms of specific incremental oil production per well $(5,010.9)$ is achieved by radial drilling. Therefore, it is recommended for oil production optimization.

Based on the results of analyzing the graphs of changes in $V_{\text {oil }}$ values depending on $V_{\mathrm{H}_{2} \mathrm{O}}$ values, in the third interval, it is recommended that Wells 404, 427 and 477 continue working in the same mode. For Wells, on which water injection into the formation has insignificant effect $(403,405,423,426,478$ и 483), radial drilling is recommended. Wells 400,425 and 474 were abandoned in 2016 because of water cut close to $100 \%$.

\section{Conclusions}

In view of the above, the statistical analysis was used to assess the impact of water injection into the formation on oil production on the example of Tournaisian deposits of Sosnovskoe oil and gas field. The research results show that the analysis described in the paper may be applied to assess the impact of water injection into the formation on oil production and provide a rationale for carrying out recovery enhancement operation and to identify hydrodynamic relations. This method of assessment shall be further applied to further development targets.

\section{References}

1. Zotikov V.I., Kozlova I.A., Krivoshchekov S.N. Geologicheskie osnovy ratsionalnoy razrabotki neftyanykh i gazovykh mestorozhdeniy [Geological basis for the rational development of oil and gas fields]. Perm, Izdatelstvo permskogo natsionalnogo issledovatelskogo politekhnicheskogo universiteta, 2012, 169 p.

2. Alvard A.A. Analiz effektivnosti sistemy zavodneniya vo-lostnovskogo neftyanogo mestorozhdeniya [Analysis of the effectiveness of the water flooding system of the Volostnovsky oil field]. Nauchno-tekhnicheskie problemy dobychi nefti $v$ starom neftedobyvayushchem regione, 2007, iss.119, part II, pp.121-128.

3. Atanov G.A., Bokserman A.A., Surguchev M.L., Tsynkova O.E. K opredeleniyu effektivnosti tsiklicheskogo zavodneniya neodnorodnykh neftyanykh plastov [To determine the effectiveness of cyclic flooding of heterogeneous oil reservoirs]. Oil industry, 1973, no.I, pp.46-49.

4. Zakharov I.V. Sozdanie metoda opredeleniya slabodreniruemykh i zastoynykh zon neftyanykh zalezhey i tekhnologii vovlecheniya ikh $\mathrm{v}$ aktivnuyu razrabotku [Development of a method for determining low-drainage and stagnant zones of oil deposits and the technology of their involvement in active development]. Ph. D. thesis. Moscow, 2007,167 p.

5. Operativnyy pereschet zapasov uglevodorodnogo syrya Sosnovskogo mestorozhdeniya na osnove geologicheskoy modeli [Express recalculation of hydrocarbon reserves of the Sosnovskoye field based on the geological model]. Perm, Filial OOO "LUKOYLInzhiniring" "PermNIPIneft" v g. Permi, 2012.

6. Xin Qi, Ruiyan Luo, Carroll R.J., Hongyu Zhao. Sparse regression by projection and sparse discriminant analysis. Journal of Computational and Graphical Statistics, 2015, 24(2), pp.416-438.

7. Urbakh V.Yu. Diskriminantnyy analiz i ego primenenie $\mathrm{v}$ biologicheskoy sistematike i meditsinskoy diagnostike [Discriminant analysis and its application in biological systematics and medical diagnostics]. Primenenie matematicheskikh metodov $v$ biologii. Leningrad, 1964, iss.3, pp.67-87

8. Kravtsov B.A., Milyutin L.I. Vozmozhnosti primeneniya mnogomernoy klassifikatsii pri izuchenii populyatsiy drevesnykh rasteniy [Ways to use multidimensional classification in studying populations of woody plants]. Prostranstvenno-vremennaya struktura lesnykh biogeotsenozov. Novosibirsk, Nauka, 1981, pp.47-65.

9. Materon Zh. Osnovy prikladnoy geostatistiki [Basics of applied geostatistics]. Moscow, 1968, 408 p.

10. Sosnin N.E. Development of statistical models for predicting oil-and-gas content (on the example of terrigenous devonian sediments of North Tatar arch). Perm Journal of Petroleum and Mining Engineering, 2012, no.5, pp.16-25.

11. Statsoft, available at: http://statsoft.ru/home/ textbook/default.htm (accessed 01 July 2018).

12. 12. Galkin V.I., Merson M.E., Galkin S.V. On the possibility of forecasting petroliferous deposits of south caspian basin with probabilistic and statistical methods. Perm Journal of Petroleum and Mining Engineering, 1999, no.1, pp.33-41.

13. Denisov S.V., Ismagilov R.N., Sidelnikov K.A. Rezultaty primeneniya metoda posledovatelnogo prognozirovaniya veroyatnostey dlya diskriminantnogo analiza slozhnykh modeley plasta [Application of 
sequential predictive probability method to discriminate between simple reservoir models]. Izvestiya Tulskogo gosudarstvennogo universiteta. Estestvennye nauki, 2009, 1, pp.211-216.

14. Mandrik I.E. On the statistical dependence between proved drilled-out undeveloped reserves and planned activities. Perm Journal of Petroleum and Mining Engineering, 2004, no.5, pp.41-45.

15. Mikhalevich I.M., Primina S.P. Primenenie matematicheskikh metodov pri analize geologicheskoy informatsii ( $\mathrm{s}$ ispolzovaniem kompyuternykh tekhnologiy) [The use of mathematical methods in the analysis of geological information (using computer technology)]. Irkutsk, Irkutskiy gosudarstvennyy universitet, 2006, part III, $115 \mathrm{p}$.

16. Galkin V.I., Barmin P.M. Statistical analysis application for impact assessment of reservoir pressure maintenance to development efficiency of tournasian deposit Opalihinskoe oil field. Perm Journal of Petroleum and Mining Engineering, 2000, no.3, pp.54-59.

17. Porotnikov A.V., Popov M.P. Gorbunova N.P. Primenenie lineynogo diskriminantnogo analiza dlya avtomaticheskogo opredeleniya proiskhozhdeniya izumruda po dannym rentgenoflyuorestsentnogo analiza [The use of linear discriminant analysis to automatically determine the origin of emerald according to $\mathrm{x}$-ray fluorescence analysis]. Trudy instituta geologii i geokhimii im. akademika A.N. Zavaritskogo. Ekaterinburg, 2013, pp.353-355.

18. Dat Thanh Tran, Moncef Gabbouj, Alexandros Iosifidis. Multilinear class-specific discriminant analysis. Pattern Recognition Letters, 2017, vol 100, pp. 131-136. DOI: 10.1016/j.patrec.2017.10.027

19. Kozhakin S.V. Statisticheskoe issledovanie nefteotdachi mestorozhdeniy Uralo-Povolzhya, nakhodyashchikhsya $\mathrm{v}$ pozdney stadii razrabotki [Statistical study of oil recovery in the Ural-Volga fields, which are at the late stage of development]. Oilfield engineering, 1972, no.7, pp.6-11.

20. Wang Jing. Functional principal component analysis for discretely observed functional data and sparse Fisher's discriminant analysis with thresholded linear constraints, 2016, available at: https://scholarworks.gsu.edu/math_diss/35 (accessed 01 July 2018).

21. Kagan E.S., Morozova I.S. Izuchenie faktorov optimizatsii poznavatelnoy deyatelnosti studentov $\mathrm{S}$ pomoshchyu metodov klasternogo i diskriminantnogo analizov [Studying the factors of optimization of students' cognitive activity using the methods of cluster and discriminant analyzes]. Sibirskaya psikhologiya segodnya. Kemerovo, Kuzbassvuzizdat, 2002, pp.36-41.

22. Giniyatullin K.G., Valeeva A.A., Smirnova E.V. Ispolzovanie klasternogo i diskriminantnogo analizov dlya diagnostiki litologicheskoy neodnorodnosti pochvoobrazuyushchey porody po granulometricheskomu sost [Application of cluster and discriminant analyses to diagnose lithological heterogeneity of the parent material according to its particle-size distribution]. Moscow, Nauka, 2017, pp. 946-953.

23. Fisher R.A. The precision of discriminant functions. Annals of Eugenics, 1940, 10, pp.422-429.

24. Cooley W.W., Lohnes P.R. Multivariate data analysis. New York, John Wiley and Sons, Inc., 1971, 364 p.

25. Krivoshchekov S.N., Galkin V.I., Kozlova I.A. Determination of potentially oil bearing areas by behavioristical method by the example of Perm region (krai). Perm Journal of Petroleum and Mining Engineering, 2012, no.4, pp.7-15.

26. Anderson T.W. An introduction to multivariate statistical analysis. New York, John Wiley and Sons, Inc., 1958, $374 \mathrm{p}$.

27. Andrewartha H.G., Birch L.C. The distribution and abundance of animals. Chicago, Univ. Press, 1954, $782 \mathrm{p}$.

28. Cacoullos T. Discriminant analysis and applications. London, Academic press, 1972, 434 p.

29. Kim Dzh.O., Myuller Ch.U., Klekka U.R. et al. Faktornyy, diskriminantnyy i klasternyy analiz [Factorial, discriminant and cluster analysis]. Moscow, Finansy i statistika, 1989, $215 \mathrm{p}$.

30. Andersen T. Vvedenie v mnogomernyy statisticheskiy analiz [Introduction to multivariate statistical analysis]. Moscow, Fizmatgiz, 1963, 500 p.

31. Friedman J. Regularized discriminant analysis. Journal of the American Statistical Association, 1989, 84, pp.165-175.

32. Morrison D.F. Applied statistical methods. Prentice-Hall, Inc, Engle-wood Cliffs, N.J., 1983, 562 p.

33. Xu P., Brock G., Parrish R. Modified linear discriminant analysis approaches for classification of highdimensional microarray data. Computational Statistics and Data Analysis, 2009, 53, pp.1674-1687.

34. Yong Wang, Jian-Bin Xie, Yi Wu. Orthogonal discriminant analysis revisited. Pattern Recognition Letters, 2016, vol. 84, pp.149-155. DOI: 10.1016/j.patrec.2016.09.010

35. Borovikov V.P. Statistica dlya studentov i inzhenerov [Statistica for students and engineers]. Moscow, KompyuterPress, 2001, 301 p.

36. Gmurman V.S. Teoriya veroyatnostey i matematicheskaya statistika [Theory of Probability and Mathematical Statistics]. Moscow, Vysshaya shkola,1972, 368 p.

37. Ayvazyan S.A., Stepanov V.S. Instrumenty statisticheskogo analiza dannykh [Statistical data analysis tools]. Mir PK, 1997, no.8.

38. Machine learning, neural and statistical classification. Ed. D. Mitchie et al. Ellis Horwood, Chichester, UK, 1994, 304 p.

39. Li C.C. Introduction to experimental statistics. McGraw-Hill, Inc., New York, 1964, 460 p.

40. Davis J.C. Statistics and data analysis in geology. 3rd ed. John Wiley \& Sons, 2002.

41. Mikhalevich I.M., Alferova M.A., Rozhkova N.Yu. Osnovy prikladnoy statistiki [Basics of Applied Statistics]. Irkutsk, Izdatelstvo gosudarstvennogo instituta usovershenstvovaniya vrachey, 2008, vol.3, p.92. 


\section{Библиографический список}

1. Зотиков В.И., Козлова И.А., Кривощеков С.Н. Геологические основы рациональной разработки нефтяных и газовых месторождений: учеб. пособие. Пермь: Изд-во Перм. нац. исслед. политехн. ун-та, 2012. - 169 c.

2. Альвард А.А. Анализ эффективности системы заводнения Волостновского нефтяного месторождения // Научно-технические проблемы добычи нефти в старом нефтедобывающем регионе. - 2007. - Вып. 119, ч. II. С. 121-128.

3. Атанов Г.А., Боксерман А.А., Сургучев М.Л., Цынкова О.Э. К определению эффективности циклического заводнения неоднородных нефтяных пластов // Нефтяное хозяйство. - 1973. - № I. - С. 46-49.

4. Захаров И.В. Создание метода определения слабодренируемых и застойных зон нефтяных залежей и технологии вовлечения их в активную разработку: дис. ... канд. техн. наук. - М., 2007. - 167 с.

5. Оперативный пересчет запасов углеводородного сырья Сосновского месторождения на основе геологической модели / Филиал ООО «ЛУКОЙЛИнжиниринг» «ПермНИПИнефть» в г. Перми. Пермь, 2012.

6. Sparse regression by projection and sparse discriminant analysis / Xin Qi, R. Luo, R.J. Carroll, Hongyu Zhao // Journal of Computational and Graphical Statistics. - 2015. - 24(2). - P. 416-438.

7. Урбах В.Ю. Дискриминантный анализ и его применение в биологической систематике и медицинской диагностике // Применение математических методов в биологии. - Л., 1964. Вып. 3. - С. 67-87.

8. Кравцов Б.А., Милютин Л.И. Возможности применения многомерной классификации при изучении популяций древесных растений // Пространственновременная структура лесных биогеоценозов. Новосибирск: Наука, 1981. - С. 47-65.

9. Матерон Ж. Основы прикладной геостатистики. M., 1968. - 408 c.

10. Соснин Н.Е. Разработка статистических моделей для прогноза нефтегазоносности (на примере терригенных девонских отложений Северо-Татарского свода) // Вестник Пермского национального исследовательского политехнического университета. Геология. Нефтегазовое и горное дело. - 2012. - № 5. C. $16-25$.

11. Statsoft: электрон. учеб. по статистике [Электронный pecypc]. - URL: http://statsoft.ru/ home/textbook/default.htm (дата обращения: 01.08.2018).

12. Галкин В.И., Мерсон М.Э., Галкин С.В. О возможностях прогнозирования нефтегазоносных отложений юга Прикаспийской впадины вероятностностатистическими методами // Вестник Пермского национального исследовательского политехнического университета. Геология. Нефтегазовое и горное дело. 1999. - № 1. - C. 33-41.
13. Денисов С.В., Исмагилов Р.Н., Сидельников К.А. Результаты применения метода последовательного прогнозирования вероятностей для дискриминантного анализа сложных моделей пласта // Известия Тульского государственного университета. Естественные науки. - 2009. - 1. - С. 211-216.

14. Мандрик И.Э. О статистических зависимостях доказанных разбуренных неразрабатываемых запасов с количеством запланированных мероприятий // Вестник Пермского национального исследовательского политехнического университета. Геология. Нефтегазовое и горное дело. - 2004. - № 5. C. 41-45.

15. Применение математических методов при анализе геологической информации (с использованием компьютерных технологий) / сост. И.М. Михалевич, С.П. Примина: учеб. пособие. - Иркутск: Изд-во Иркут. гос. ун-та, 2006. - Ч. III. - 115 с.

16. Галкин В.И., Бармин П.М. Применение статистического анализа для оценки влияния поддержания пластового давления на эффективность разработки турнейской залежи Опалихинского нефтяного месторождения // Вестник Пермского национального исследовательского политехнического университета. Геология. Нефтегазовое и горное дело. 2000. - № 3. - С. 54-59.

17. Поротников А.В., Попов М.П. Горбунова Н.П. Применение линейного дискриминантного анализа для автоматического определения происхождения изумруда по данным рентгенофлюоресцентного анализа // Труды института геологии и геохимии им. академика А.Н. Заварицкого. - Екатеринбург, 2013. - С. 353-355.

18. Dat Thanh Tran, Moncef Gabbouj, Alexandros Iosifidis. Multilinear class-specific discriminant analysis // Pattern Recognition Letters. - 2017. - Vol 100. P. 131-136. DOI: 10.1016/j.patrec.2017.10.027

19. Кожакин С.В. Статистическое исследование нефтеотдачи месторождений Урало-Поволжья, находящихся в поздней стадии разработки // Нефтепромысловое дело. - 1972. - № 7. - С. 6-11.

20. Wang Jing. Functional principal component analysis for discretely observed functional data and sparse Fisher's discriminant analysis with thresholded linear constraints, 2016 [Электронный pecypc]. URL: https://scholarworks.gsu.edu/math_diss/35 (дата обращения: 01.08.2018).

21. Каган Е.С., Морозова И.С. Изучение факторов оптимизации познавательной деятельности студентов с помощью методов кластерного и дискриминантного анализов // Сибирская психология сегодня. Кемерово: Кузбассвузиздат, 2002. - С. 36-41.

22. Гиниятуллин К.Г., Валеева А.А., Смирнова Е.В. Использование кластерного и дискриминантного анализов для диагностики литологической неоднородности почвообразующей породы по гранулометрическому составу. - М.: Наука, 2017. - С. 946-953. 
23. Fisher R.A. The precision of discriminant functions // Annals of Eugenics. - 1940. - 10. P. 422-429.

24. Cooley W.W., Lohnes P.R. Multivariate data analysis. New York, John Wiley and Sons, Inc., 1971. - 364 p.

25. Кривощеков С.Н., Галкин В.И., Козлова И.А. Определение перспективных участков геологоразведочных работ на нефть вероятностностатистическими методами на примере территории Пермского края // Вестник Пермского национального исследовательского политехнического университета. Геология. Нефтегазовое и горное дело. - 2012. - № 4. C. $7-15$.

26. Anderson T.W. An introduction to multivariate statistical analysis. - New York, John Wiley and Sons, Inc., 1958. $-374 \mathrm{p}$.

27. Andrewartha H.G., Birch L.C. The distribution and abundance of animals. - Chicago: Univ. Press, 1954. $782 \mathrm{p}$.

28. T. Cacoullos. Discriminant analysis and applications. London: Academic press, Inc., 1972. - 434 p.

29. Факторный, дискриминантный и кластерный анализ / Дж.О. Ким, Ч.У. Мьюллер, У.Р. Клекка [и др.]. - М.: Финансы и статистика, 1989. - 215 с.

30. Андерсен Т. Введение в многомерный статистический анализ. - М.: Физматгиз, 1963. - 500 с.

31. Friedman J. Regularized discriminant analysis // Journal of the American Statistical Association. - 1989. 84. - P. 165-175.
32. Morrison D.F. Applied statistical methods. Prentice-Hall, Inc, Engle-wood Cliffs, 1983. - 562 p.

33. Xu P., Brock G., Parrish R. Modified linear discriminant analysis approaches for classification of highdimensional microarray data // Computational Statistics and Data Analysis. - 2009. - 53. - P. 1674-1687.

34. Yong Wang, Jian-Bin Xie, Yi Wu. Orthogonal discriminant analysis revisited // Pattern Recognition Letters. - 2016. - Vol. 84. - P. 149-155. DOI: $10.1016 /$ j.patrec.2016.09.010

35. Боровиков В.П. Statistica для студентов и инженеров. - М.: КомпьютерПресс, 2001. - 301 с.

36. Гмурман В.С. Теория вероятностей и математическая статистика. - М.: Высшая школа, 1972. - 368 c.

37. Айвазян С.А., Степанов В.С. Инструменты статистического анализа данных // Мир ПК. - 1997. № 8 .

38. Machine learning. Neural and statistical classification / Ed. D. Mitchie [et al.]. - Ellis Horwood, Chichester, 1994. - 304 p.

39. Li C.C. Introduction to experimental statistics. New York: McGraw-Hill, Inc, 1964. - 460 p.

40. Davis J.C. Statistics and data analysis in geology. 3rd ed. - John Wiley \& Sons, 2002.

41. Михалевич И.М., Алферова М.А., Рожкова Н.Ю. Основы прикладной статистики: в 3 т. - Иркутск: Изд-во Гос. ин-та усовершенствования врачей, 2008. T. $3 .-92$ c.

Please cite this article in English as:

Fadeev A.P. A procedure for evaluation of the effect of water injection into a reservoir on oil production on example of Tournaisian deposits of the Sosnovskoe gas-oil field. Perm Journal of Petroleum and Mining Engineering, 2018, vol.18, no.2, pp.157-177. DOI: $10.15593 / 2224-9923 / 2018.4 .6$

Просьба ссылаться на эту статью в русскоязычных источниках следующим образом:

Фадеев А.П. Разработка методики оценки влияния закачки воды в пласт на добычу нефти на примере турнейских отложений Сосновского газонефтяного месторождения // Вестник Пермского национального исследовательского политехнического университета. Геология. Нефтегазовое и горное дело. - 2018. - Т.18, №2. - C.157-177. DOI: 10.15593/2224-9923/2018.4.6 